\title{
Geologic Effects of the
}

High-Explosive Tests

in the USGS Tunnel Area

Nevada Test Site

GEOLOGICAL SURVEY PROFESSIONAL PAPER 382-B

Prepared on behalf of the U.S. Atomic Energy Commission and published with the permission of the Commission

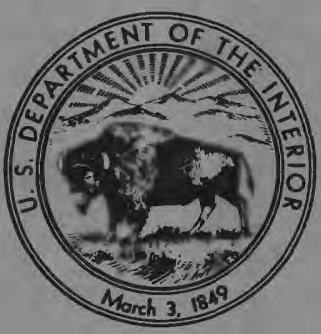




\section{Geologic Effects of the}

\section{High-Explosive Tests}

\section{in the USGS Tunnel Area}

Nevada Test Site

By J. M. CATTERMOLE and W. R. HANSEN

GEOLOGIC INVESTIGATIONS RELATED TO NUCLEAR EXPLOSIONS

GEOLOGICAL SURVEY PROFESIONAL PAPER $382-\mathrm{B}$

Prepared on behalf of the U.S. Atomic Energy

Commission and published with the permission

of the Commission

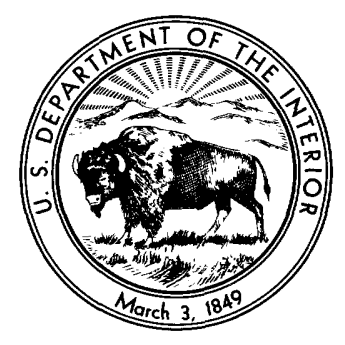

UNITED STATES GOVERNMENT PRINTING OFFICE，WASHINGTON : 1962 


\section{UNITED STATES DEPARTMENT OF THE INTERIOR \\ STEWART L. UDALL, Secretary}

\section{GEOLOGIGAL SURVEY}

Thomas B. Nolan, Director

For sale by the Superintendent of Documents, U.S. Government Printing Office

Washington 25, D.C. 


\title{
CONTENTS
}

\author{
Abstract.-. \\ Introduction . \\ B-1 \\ The 10-ton explosion in room $\mathrm{A}$ \\ Surface effects \\ B-10 \\ Purpose of the high-explosive tests . . . . . . . . . . \\ Purpose of the report. \\ Acknowledgments ................................. \\ Underground effects $\ldots \ldots \ldots \ldots$ \\ The 50-ton explosion in room $\mathrm{B}_{\ldots} \ldots \ldots$ \\ Surface effects............ \\ Surface fracturing \\ Permanent updoming over room B........... 24 \\ Location, dimensions, and design of the tunnel. .... \\ Geologic summary (preshot). \\ Tests for containment of small explosions . . . . . . . . .

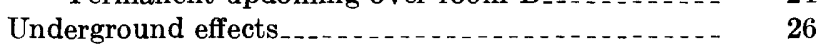 \\ Containment of the 10-ton and 50-ton shots........ 28 \\ Literature cited...... 29 \\ Index
}

Page

Page

\section{ILLUSTRATIONS}

\section{[Plates are in pockets]}

Plate 1. Geologic map and columnar section of the USGS Tunnel area.

2. Geologic map of the USGS Tunnel prior to the high-explosive tests.

3. Effect of 10-ton shot on geology and workings, USGS Tunnel area.

4. Effect of 50-ton shot on geology and workings, USGS Tunnel area.

5. Pattern of fractures opened by 50-ton explosion, USGS Tunnel area.

6. 10-ton-explosion debris in USGS Tunnel.

FIGURE 1. Pattern of fractures opened by 10-ton explosion, USGS Tunnel area

2. Small faults in north wall of room $\mathrm{B}$ before 50-ton explosion

3. $A$, Theoretical zones of breakage of an explosive force. $B$, Actual shape of breakage with relatively low force of explosion. $C$, Increased force of explosion

4. Effects of contained explosion exposed by careful excavation

5. Map showing permanent uplift resulting from 10-ton explosion

6. Jetlike dust cloud emerging from tunnel after 10-ton explosion

7. Map of USGS Tunnel showing stemming

8. Views north in the main tunnel at station $2+00$ before and after 10-ton explosion in room A

9. Underground effect of 10-ton explosion

10. Diagrammatic cross section through postshot cavity after 10-ton explosion

11. North wall of room $A$ after 10-ton explosion

12. Slickensides on back of main tunnel near station $1+95$ after 10-ton explosion

13. Sharp uplift over room $B$ caused by 50-ton explosion

14. Large fractures just north of ground zero, 50-ton blast

15. Large northward-trending fracture 35 feet east of ground zero, 50-ton blast ...

16. View west toward ground zero, 50-ton explosion

17. Low scarp formed by shifting of bedding planes 500 feet south of room $\mathrm{B}$, after 50 -ton explosion

18. Comparative views of portal area, USGS Tunnel before and after 50-ton dynamite explosion in room $\mathrm{B}$. . . . . -

19. Identical scarps in colluvium formed by low-angle displacement, $A$, and high-angle displacement, $B$

20. Canted outline of tunnel between stations $2+67$ and $2+84 \ldots$ 


$$
+
$$




\title{
GEOLOGIC INVESTIGATIONS RELATED TO NUCLEAR EXPLOSIONS
}

\section{GEOLOGIC EFFEGTS OF THE HIGH-EXPLOSIVE TESTS IN THE USGS TUNNEL AREA, NEVADA TEST SITE}

\author{
By J. M. Cattermole and W. R. Hansen
}

\begin{abstract}
During the winter and spring of 19.56-57 the U.S. Geological Survey ran a series of underground high-explosive tests at the Nevada Test Site. The purpose of these experiments, and of the subsequent relatively low yield Rainier nuclear blast, was to determine the feasibility of underground detonation as a method of testing atomic devices. In developing parameters for the effectiveness of various-sized explosions in rock, the following formula relating to depth of containment was used :
\end{abstract}

$$
D=k \sqrt[3]{W}
$$

where $D=$ depth of cover, in feet

$k=$ constant

$W=$ weight of explosive in pounds.

Although this formula has limitations, its use provides a good empirical basis for estimating the jrobable behavior of a given underground explosion.

The USGS Tunnel consists of a main access-way 308 feet long and two lateral tunnels oriented at right angles to the main tunnel and terminated in explosion chambers, rooms $\mathrm{A}$ and $\mathrm{B}$ (10-ton and 50-ton explosion chambers, respectively). The workings were dug in tuffaceous pyroclastic rock of the Oak Spring formation of Tertiary age. This rock, which is rhyolitic to quartz latitic, consists chiefly of altered ash shards and pumice fragments but contains various phenocrysts of quartz, feldspar, and mafic minerals, and lithic inclusions. The rock is tunneled easily and generally stands well underground without support.

Several small explosive charges of various sizes were fired in drill holes at various depths in the Oak Spring formation. These charges gave values for $k$ in the formula that ranged from 2.45 to 3.33 .

The 10-ton explosion was fired in room A on February 21, 1957, under 92 feet of minimum cover. A roughly oval area covering about 3.700 square feet was permanently raised 1 foot or more above its former position, and a subcircular area of nearly 12,000 square feet was lifted half a foot or more. Numerous fractures that were opened at the ground surface coincided chiefly with preexisting natural fractures. An instant after the shot was detonated, a horizontally directed blast of gas, dust, and rock emerged at high velocity from the portal of the tunnel. Underground, part of the wall of the explosion chamber had failed, permitting the gas generated by the explosion to bypass the stemming. The explosion chamber itself was greatly enlarged by the blast.
The 50-ton explosion was fired in room B on April 5, 1957, under a minimum of 165 feet of cover. This explosion temporarily updomed the ground surface above the chamber about 26 feet and permanently lifted it locally as much as 6 feet. The area strongly disturbed by the blast covers about 12,000 square yards and is roughly triangular in shape. Most of the strongest surface displacements were along preexisting fractures, but many surface fractures were formed within previously sound rock. Within 200 feet of ground zero the fracture pattern in previously sound rock was radial. Underground, the rock was severely fractured around the explosion chamber and the tunnel was closed by debris. Subsequently, entry to the chamber was reestablished, but most of the debris was not removed.

As classed by their surface and underground effects, the 10ton and 50-ton explosions were not fully contained. The $k$ factor for containment of the 10-ton shot is calculated as 3.7, and 9.3 tons of 60-percent gelatin dynamite would be the amount for exact containment. The $k$ factor for containment of the 50-ton shot is calculated as 4.1, and 38.2 tons of dynamite would be the amount for exact containment.

\section{INTRODUCTION}

\section{PURPOSE OF THE HIGH-EXPLOSIVE TESTS}

In the summer of 1956 the U.S. Atomic Energy Commission requested information and advice from the U.S. Geological Survey about the feasibility of exploding nuclear weapons underground. Underground testing of nuclear devices was being considered as a means of averting the detrimental effects of aboveground blasts, such as radioactive fallout, shock and flash, and as a means of circumventing the time restrictions imposed by rather rigid weather requirements of aboveground tests. After a study of the available literature on the geologic effects of explosives, the Geological Survey proposed that a series of tests with conventional high explosives precede any nuclear explosion underground. The Atomic Energy Commission agreed, and a site later to be known as the USGS Tunnel area was chosen in the Atomic Energy Commission's Nevada Test Site about 70 miles northwest of 
Las Vegas, Nev. Work on the USGS Tunnel was started in December 1956, and by late February 1957, the tunnel and two explosion chambers were virtually complete.

The Atomic Energy Commission desired that the underground nuclear explosion would be contained to the extent that no radioactive contamination would escape from the explosion chamber through fractures in the rock into the atmosphere. To develop a scale for the depth of burial necessary for containment of nuclear explosions and to establish parameters of value in forecasting the behavior of rocks in nuclear explosions, 10 and 50 tons of dynamite were exploded in chambers in the USGS Tunnel under carefully assessed geologic conditions. Subsequently, the first underground nuclear explosion-the Rainier test-was fired in September 1957.

The Rainier nuclear explosion, with a rated yield of 1.7 kilotons of TNT, was a small-scale test by atomic standards. Together with the high-explosive tests in the USGS Tunnel, the relatively low yield Rainier nuclear explosion established the feasibility of underground detonation as a method of testing atomic devices. Since this report was first prepared (June 1957), several devices of larger yield have been fired underground.

In the United States, many formulas for the effects of explosives have been based on the cube of the distance, or upon the cube root of the weight of the explosive. Peele (1918, p. 190) gives the formula $C=\frac{P}{l^{3}}$ in which $C=$ rock coefficient; $1=$ line of least resistance, in feet; $P=$ weight of powder, in pounds. Du Pont de Nemours \& Co. (1954, p. 133) for sympathetic detonation of explosives above ground gives the formula $d=k w 1 / 3$, in which $d=$ distance; $k=\mathbf{a}$ constant proportional to the sensitivity of the explosive; and $w=$ weight of the explosive. Livingston $(1956$, p. 3$)$ for dissipation of an explosive into the solid without visible damage to the surface gives a formula $N=E \sqrt[3]{W_{c}}$, in which $N$ is the critical depth, in feet; $E$ is the strain-energy factor; $W_{c}$ is the critical weight of the explosive, in pounds.

To develop parameters for the effectiveness of various-sized explosions in the Oak Spring formationthe rock in which all the tests including the Rainier test were fired-the following formula relating to depth of containment was used:

$$
D=k \sqrt[3]{W} \text { or } D=12.6 k \sqrt[3]{W_{1}}
$$

where $D=$ depth of cover, in feet

$k=$ constant

$W=$ weight of explosives, in pounds

$W_{1}=$ tons of explosives.
The limitations of the formula should be pointed out. The constant $k$ is affected by such factors as specific gravity, compressive and tensile strength of the rock involved, extent and orientation of rock fractures, faces to which the explosion may break, speed of transmission of the shock waves, and type of explosive. Many of these factors and the interaction between them are themselves variables of unknown quantity, and thus, a value for $k$ obtained from a series of tests at one site might differ appreciably from the value obtained elsewhere under apparently similar conditions. Even so, such tests provide the best basis for estimating the probable behavior of a given underground explosion.

\section{PURPOSE OF THE REPORT}

The following report describes primarily the geologic effects of the high-explosive tests on the rocks of the USGS Tunnel area and reports the influence of geologic features on the behavior of the tests. Various other explosion effects, such as seismic effects, were also observed and measured by the U.S. Geological Survey and will be described separately by other authors. The geologic effects of the Rainier atomic test are also described separately.

\section{ACKNOWLEDGMENTS}

The general organization of the high-explosive tests, including the location, dimensions, and design of the tunnel and the placement of the explosives, resulted from the concerted planning of many individuals. Those principally involved include Ernest Dobrovolny, E. B. Eckel, C. B. Read, W. H. Diment, and J. M. Cattermole, of the Geological Survey. This report was prepared under the general supervision of $\mathrm{Mr}$. Dobrovolny. He and Mr. Eckel made the preliminary geologic investigations that led to selection of the tunnel site.

E. W. Felegy, subdistrict supervisor, U.S. Bureau of Mines, was consultant to the Geological Survey on explosives, stemming, and safety factors.

\section{METHODS OF STUDY}

Before the high-explosive tests in the USGS Tunnel were run, the geology of the tunnel and of the enclosing area-about 20 acres-was carefully mapped. The surface geology (pl. 1) was mapped by W. R. Hansen and R. W. Lemke at a scale of 50 feet per inch, using telescopic alidade and planetable and ground control previously established by Holmes and Narver, AEC engineering contractors. Warren L. Peterson was instrumentman for most of the planetable work. The underground geology was mapped by J. M. 
Cattermole at a scale of 10 feet per inch, using steel tape and control by Holmes and Narver, supplemented by planetable and alidade. In mapping underground, Cattermole used projections of both walls and the back (ceiling). In these projections (pls. 2-4) the center strip is the plan of the back; the two strips adjoining the plan are profiles of the walls rotated outward to the horizontal plane along the line that joins the top of the walls to the back. In mapping before the explosions, the tunnel was assumed to be rectangular; where the tunnel departed from a rectangular shape, the mapped features were projected into the plane of the assumed rectangle.

Cattermole conducted a series of tests to determine experimentally the value of the $k$ factor in the formula for depth of containment. Measured amounts of dynamite were exploded in drill holes of different depths to establish the ratio between weight of explosive and depth of rock cover required for containment.

After the large explosions (10-ton and 50-ton) both the surface and the underground were reexamined, and all significant changes were noted and mapped. Surface effects of the 10-ton explosion (fig. 1) were mapped by planetable and alidade at a scale of 20 feet per inch by Lemke, Peterson, and Hansen. Surface effects of the 50-ton explosion (pl. 5) were mapped by Hansen at a scale of 50 feet per inch, using a planetable, steel tape, open-sight alidade, and previously established control. The underground geology was remapped by Cattermole at the original scale. Peterson was instrumentman and helped in the postshot mapping.

Precision ground surveys for horizontal and vertical displacement were run by Holmes and Narver before and after both explosions along radiating traverses centered over both explosion chambers. Underground surveys also were run before and after both explosions.

Unless otherwise credited, all photographs reproduced on the following pages, both above and below ground, were taken by Hansen.

\section{LOCATION, DIMENSIONS, AND DESIGN OF THE TUNNEL}

The USGS Tunnel is located in the northwestern part of the Nevada Test Site in the Tippipah Spring quadrangle about 40 road miles from Camp Mercury, Nev. The main access tunnel, oriented N. $22^{\circ}$ E., is 308 feet long. Two lateral tunnels oriented at right angles to the main tunnel terminate in the explosion chambers, rooms $\mathbf{A}$ and B. Room A was designed to hold 10 tons of high explosives and room B, 50 tons. Figure 7 is a plan of the tunnel (preshot) showing the layout of the workings and the position of the stemming used to confine the blasts.
Room B was designed to be self sealing; the stemming was largely precautionary. The lateral tunnel to room $B$ was turned back upon itself so that the force of the explosion would close the tunnel by driving a mass of rock from the wall of the explosion chamber into the tunnel. This design duplicated in principle the design proposed and later used for the Rainier atomic explosion (Johnson and others, 1958, p. 8).

Specifications called for the tunnels to be 4 feet wide by 6.5 feet high; room $\mathbf{A}$ to be 5 feet wide, 8 feet long, and 8 feet high; and room $B$ to be 11 feet in all 3 dimensions. Because of overbreakage, the excavated dimensions were somewhat irregular. Room $\mathbf{A}$ was in effect as specified; but room B was about 12 feet wide west to east, about 12 feet high, and about 14 feet long north to south. Room $\mathbf{A}$ had a vertical rock cover of 123.4 feet, but the shortest distance from the center of the room to the ground surface, owing to topographic configuration, was 92 feet. Room B had 174.1 feet of vertical cover, and the shortest distance to the ground surface was 165 feet.

\section{GEOLOGIC SUMMARY (PRESHOT)}

The geology of the area has already been described by Hansen and others (1962), and therefore will be summarized but briefly here. The area is underlain by the Oak Spring formation (Johnson and Hibbard, 1957 , p. 367) of late Miocene(?) or younger age, a sequence of tuffaceous pyroclastic rocks. In the nearby Rainier Tunnel area, about 2 miles to the west, the Oak Spring formation is divisible into 8 map units that are identified by number. Only units 2,3 , and 4 crop out in the small USGS Tunnel area (pl. 1), but lower and higher units occur in the slopes nearby.

The tuff at the USGS Tunnel has a rhyolitic to quartz-latitic composition. It consists chiefly of devitrified ash shards and pumice lapilli, but it contains phenocrysts of quartz, feldspar, and biotite, and more rarely, pyroxene and amphibole. It also contains lithic inclusions of various volcanic and sedinentary rocks, notably quartzite. It has a low bulk density and a corresponding high porosity, but its permeability is low. The water content of the rock is as much as $\mathbf{1 5}$ to 25 percent by weight in fresh samples. The rock can be drilled and blasted easily and stands well underground without support; the only timbering in the tunnel before the high-explosive shots was at the portal (fig. 18) and at station $2+65$ in the main tunnel in a zone of heavy ground caused by a fault.

Within the tunnel area the structure is homoclinal. The beds dip mostly to the northeast, generally at angles of less than $15^{\circ}$. Local departures from the general 


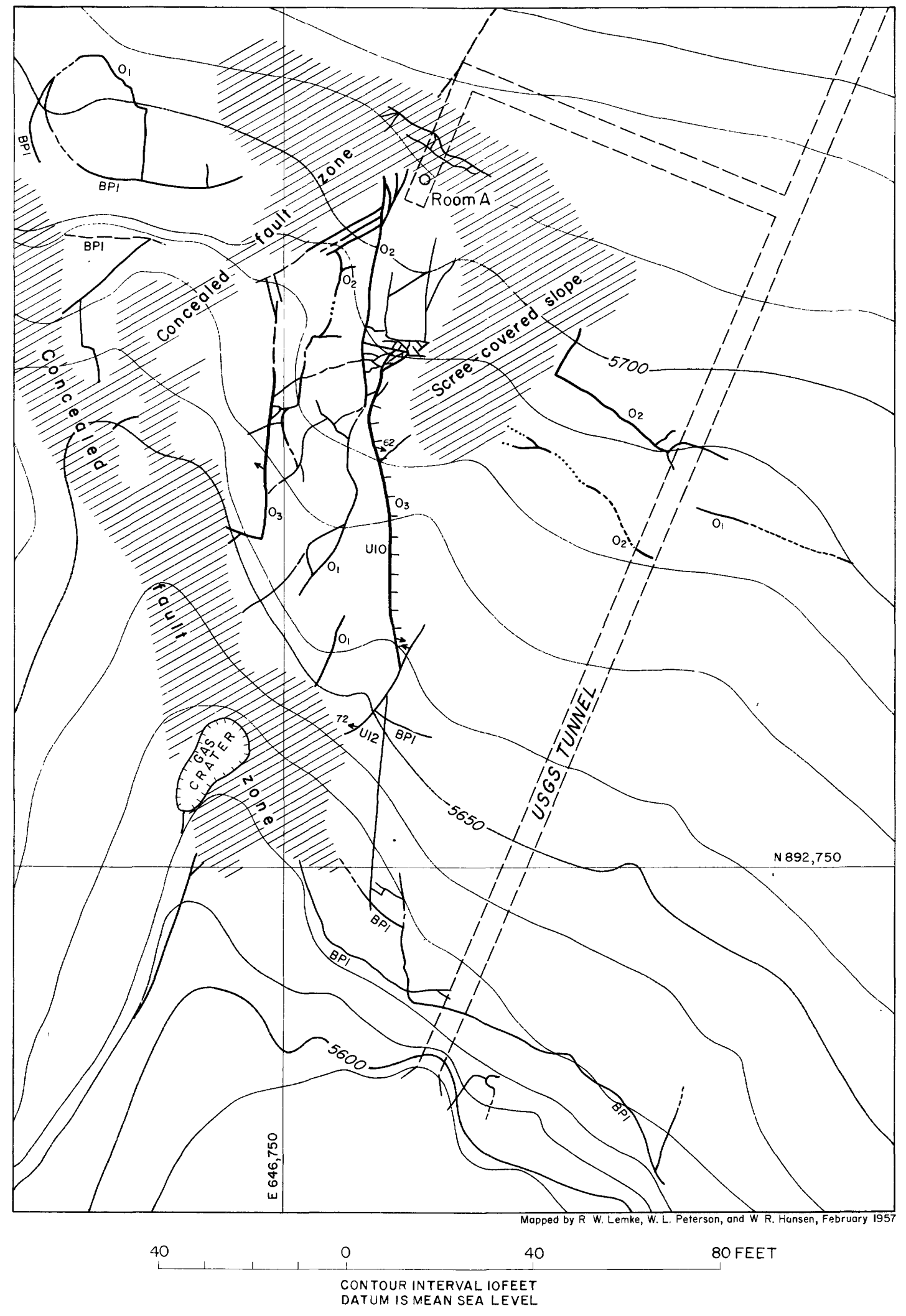

EXPLANATION

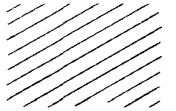

Overburden

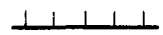

Scarp, hachures on downthrown side

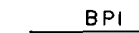

Bedding-plane break Uio

Fracture with vertical displacement, showing relative displacement, in inches

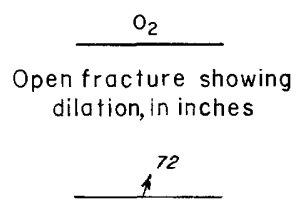

Direction and amount of dip of fracture

Figure 1.-Pattern of fractures opened by 10-ton explosion, USGS Tunnel area. 
attitude are common, especially along or near faults where the departures are caused by drag.

Small normal faults are fairly abundant in the area, although the only sizable one cut by the tunnel is at station $2+65$. This fault has a maximum stratigraphic throw of about 65 feet. A small seemingly unimportant fault near the end of the main tunnel at station $3+05$ proved to be of great significance in the 50-ton experiment. This fault had no detected displacement at the ground surface before the explosion, and its throw in the tunnel was only about 15 inches. At the time of the 50-ton blast, however, it served as the prime plane of weakness at the ground surface where differential movement produced a surface scarp 5 feet high at the point of maximum offset (fig. 15, pl. 5).

Before the 10-ton shot, high-angle joints were abundant above ground in the rocks near room $\mathrm{A}$. Room $\mathrm{A}$, in fact, was intentionally located in a much-jointed area to test the behavior of high explosives in fractured ground (Ernest Dobrovolny and E. B. Eckel, written communication, 1956). Underground, joints were tightly closed; thus they were less conspicuous than at the surface where they had been accentuated by weathering, although most of those underground were marked by narrow alteration bands. Above room B, before the 50-ton shot, the ground was structurally sound and was relatively free of joints. Underground, a few small fractures with small but compensatory displacements were uncovered in room $B$ before the explosion (fig. 2), but the effect they may have had on the blast pattern was completely masked by the severe breakage in the vicinity of the room after the blast.

\section{TESTS FOR CONTAINMENT OF SMALI، EXPLOSIONS}

To establish the value of $k$ in the formula for depth of containment $(D=k \sqrt[3]{W})$, the depth of rock cover needed to contain completely the detonation of various weights of explosives was determined by Cattermole by a series of small dynamite explosions in shallow drill holes. A comparision was also made on the breaking power of 40 percent dynamite with 60 percent dynamite. Holes 2.5 to 8 feet deep were drilled in tuff (Oak Spring formation unit 3) similar to that in the USGS Tunnel. The estimated maximum weight of dynamite that could be contained at a given depth was tamped, stemmed with moist clay or concrete, and fired. If the explosion was contained in the first attempt, increased amounts of dynamite were fired in holes of the same depth until the amount needed just to break the surface was found. Conversely, if the first charge was too heavy, the amount of dynamite was decreased until an explosion was contained. In these tests the shape of the explosive charges was cylindrical. The breakage resulting from a cylin- drical charge differs to some extent from that of a spherical charge; but as the length of cylindrical charge decreases in relation to the depth of burial, the effects become more similar.

To develop a practical scale of the effects of explosives upon a particular medium, many dimensions, quantities, and qualities must be taken into account. The criteria used for determining the effects of explosives upon media in these tests were the permanent blast results. The first prerequisite for scaling of explosives is that a set of results can be directly compared only to results of a similar nature. As this principle occasionally has been overlooked, a simple explanation is in order. The first consideration is that to accomplish work on an enclosing medium the force of an explosion must be in excess of the strength of the medium. Theoretically, in an isotropic solid substance the ideal explosive force is transmitted spherically outward from a center. In the resulting zone of influence radial stress varies inversely with the cube of the radius. The dimensions of the zone of influence depend upon the force of the explosion and upon the physical properties of the enclosing medium (such as elasticity, compressive and tensile strength, limiting dimensions, and configuration).

The zone of influence can be subdivided into an inner and outer zone of breakage. For clarity, it is best to consider the forces first, and then consider these forces in relation to the factors within the zones that make the results random. The originating explosive force is a compressional, or positive, stress that in effect moves each particle radially outward from the source. Following the compressional stress is a tensile, or negative, stress that may be likened to rebound with each particle attempting to return toward its original position.

The zones of breakage of an explosion enclosed in a brittle material, such as rock, are an inner zone of compressional breakage and an outer zone of tensile breakage that may or may not develop or that is distorted from the theoretical spherical shape. The inner zone of breakage is the region in which the compressive force exceeds the strength of the rock. Compressive breakage in rock takes place by crushing, granulation, and shear fractures. Shear fractures are oriented generally at some angle between $25^{\circ}$ and $35^{\circ}$ from the direction of application of the force. The compressional force decreases gradationally outward with corresponding decrease in the amount of breakage until the outer limit of the zone of compressional breakage marks the area in which the compressional forces is less than the strength of the enclosing rock.

The tensile strength of rock is but a fraction (on the order of $1 / 20$ to $1 / 40$ ) of the compressive strength; so 


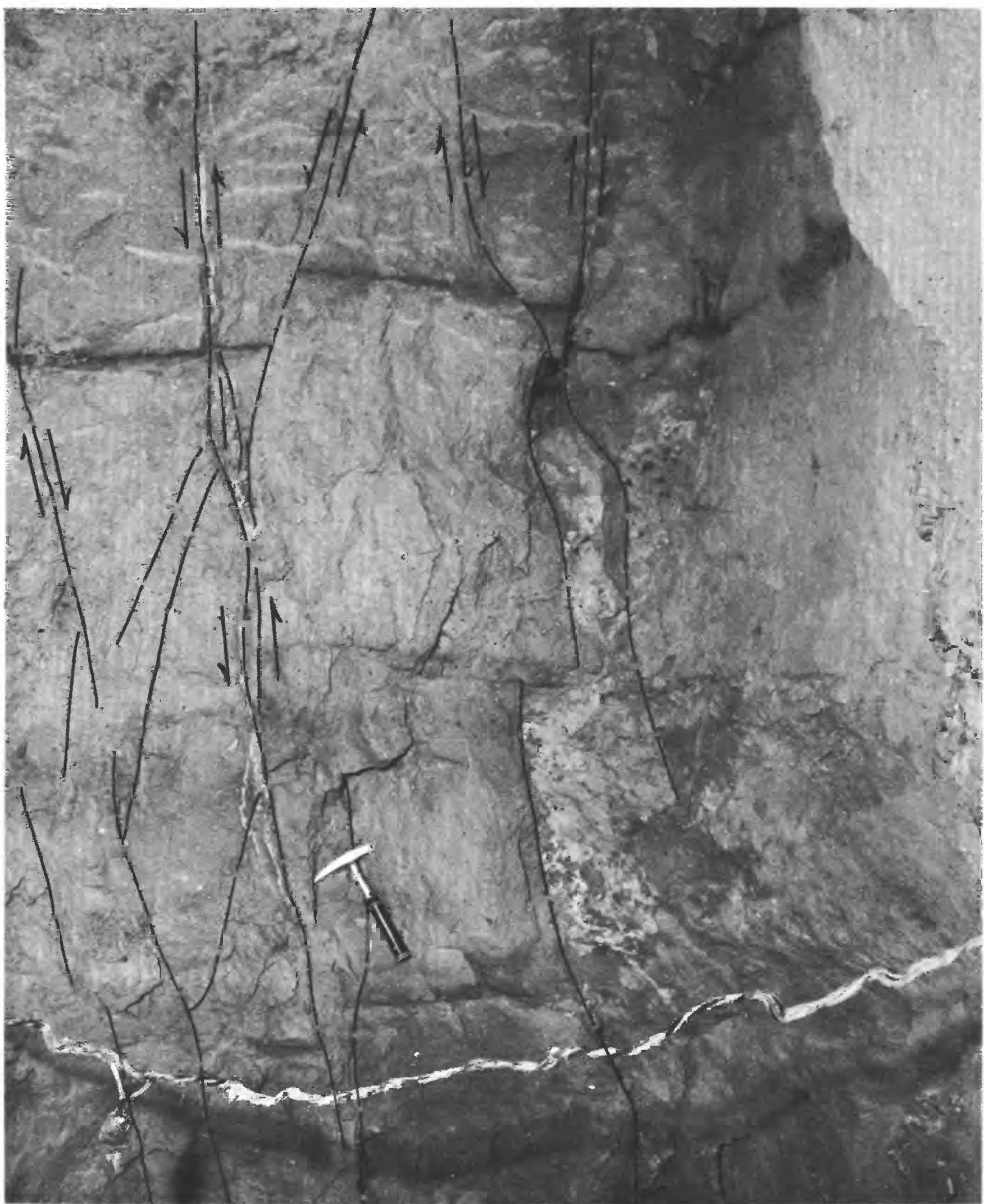

FIGURE 2.- Small faults in north wall of room B before 50-ton explosion. Most of the displacements are compensatory so that the movement on one fault tends to cancel out the movement on another. 
tensile forces may break the rock well beyond the zone of compressive breakage. Theoretically, the zone of tensile breakage would be a spherical shell surrounding the inner zone of compressive breakage, but tensile breakage rarely develops in true spherical shape. The reason for this is the influence that the degree of confinement, or latitude of movement, exerts upon breakage resulting from tensile stresses. If the magnitude of an explosion in relation to the depth of burial, or distance to a free face, is such that the stress exceeds the tensile strength upon intercepting a free face, breakage results on the free-face side where there is latitude of movement. For any area where the stress decays below the tensile strength before reaching a free face, the physical properties of elasticity or compressibility within the media will determine the tensile breakage.

Tensile fractures are of two kinds-those parallel to radii (fig. $3 A$ ) and others oriented in a circular pattern with center coinciding with the explosion point. The tensile fractures parallel to the radii are the indirect resultant of the originating compressive wave, which, as it moves outward from the explosion center, is in effect a radial outward movement of the surrounding mass. Within the mass internal tensile stresses that act parallel to the direction of the ares tend to separate the mass into wedge-shaped components. The concentric tensile fractures are opened upon rebound of the rock, and since rock rarely has equal strength in all directions, a preferred orientation is imposed upon these fractures. In sedimentary rocks this orientation generally is along bedding planes.

With an increase in explosive force to that at which the tensile strength is exceeded at a bounding limit of the medium, a mass is permanently displaced outward beyond the free face. The shape of this mass, as indicated by the tests, is conical with base at the free face and vertex toward the explosion center (fig. $3 B$ ). This explosion cone may deviate from a true cone by either convexity or concavity of the wall. Except for the vertex which may be in the zone of compressive breakage, the mass within the cone is broken up by tensile fractures. Within the cone the concentric fractures cause doming over the shot point, and a second set of fractures radiate from the axis of the cone. Figure 4 illustrates a small fully contained explosion in which the zone of compressive breakage is apparent, but tensile breakage is slight and entirely confined to a cone-shaped area where the free face provided latitude of movement.

Upon additional increase of the force of the explosion the cone of tensile breakage becomes a cone-incone structure-a hollow outer cone of tensile breakage with the rock in place surrounding an inner cone of disruption. The small tests for containment indicated that the angle subtended by the cone of disruption and the surrounding cone of tensile breakage is increased with increase of force. These tests also indicated that the vertex of these cones in relatively low energy explosions is between the explosion center and the free face (outside the zone of compressive breakage), but in increasing higher energy explosions the vertex is closer to, and finally coincides with, the explosion center (fig. $3 C$ ).

If the zone of breakage intercepts more than one free face, the shape of the broken mass is influenced. Also, the force of gravity cannot be neglected, especially in reference to the final shape and the boundary between cone of disruption and the cone of tensile breakage. As far as could be ascertained by the tests, dimensions and configuration of the enclosing medium do not exert much influence on the size or shape of the zone of compressive breakage.

With so many factors influencing the amount, degree, shape, and limits of breakage resulting from a given explosion, it should be readily understood that any attempt to determine forces of explosions by direct comparison of the breakage of a fully contained explosion to one that fractures, or craters, is meaningless.

In the tests for containment the effects of explosions were arbitrarily divided into four categories:

1. No surface effects on rocks. One contained explosion was exposed by careful excavation (fig. 4) so that the effects below the surface could be observed. The hole around the charge was expanded to about three times the original diameter. The rock for a distance of about a foot surrounding the expanded hole was minutely fractured.

2. Incipient fracturing. Hairline cracks develop along planes of weakness, such as joints or bedding planes, but there is no open fracturing.

3. Fracturing. The surface is openly fractured in a definite pattern, but few blocks are out of place or jumbled. Surface doming over the shot point is apparent. Bordering fractures, in general, dip in toward the shot point. Above the shot point is an area in which the fractures are mainly radial. The focal point of the radial fractures (axis of cone) is the area of maximum breakage, and under most conditions it is the point on the surface closest to the shot.

4. Cratering. A cone-shaped crater is developed with broken material thrown out by the force of the explosion. The depth and width of the crater have a direct relation to the force of the explosion. An explosion underenergized for complete cratering has the 

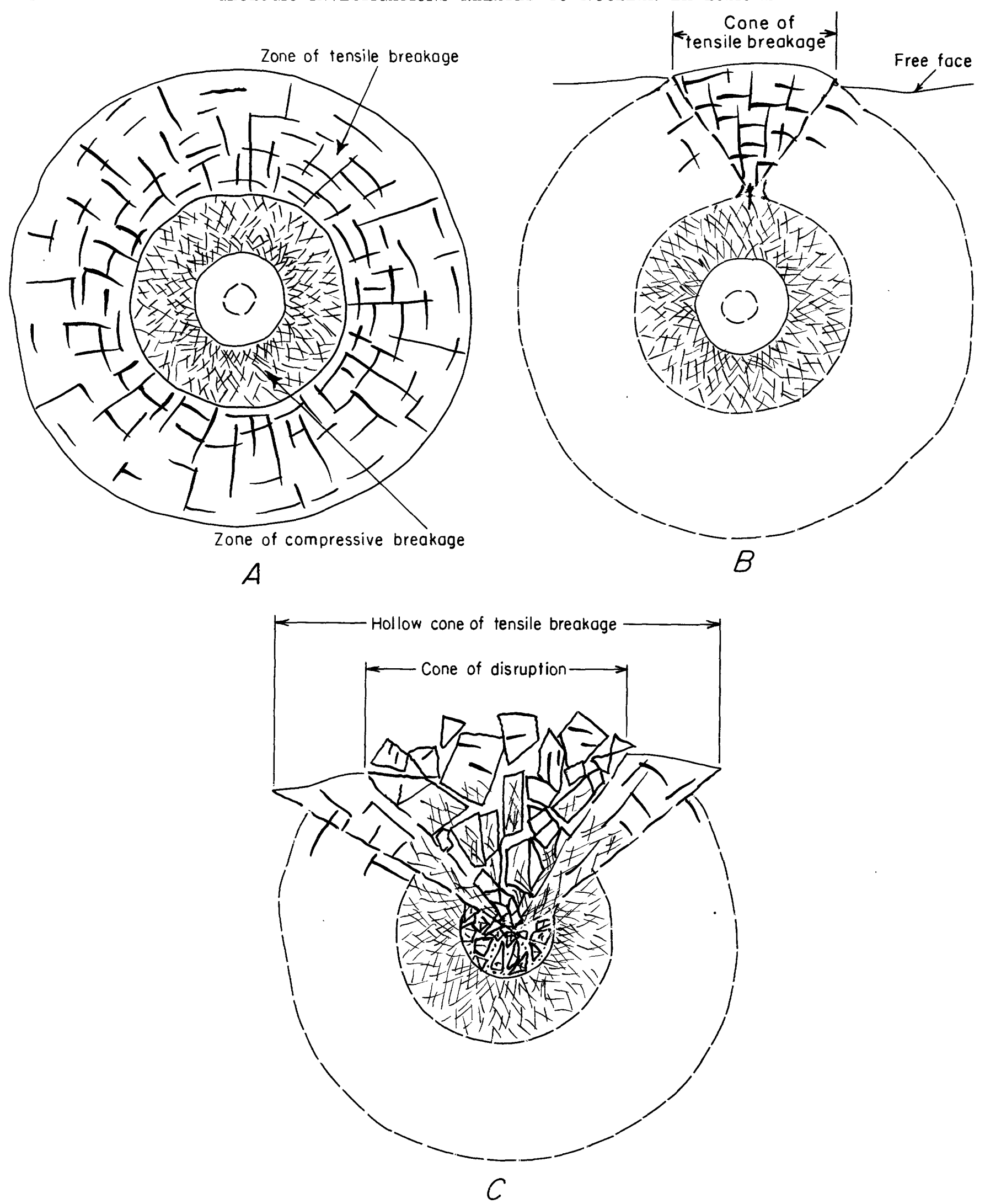

FIGURE 3.-A, theoretical zones of breakage of an explosive force in an isotropic solid medium. $B$, Actual shape of breakage with relatively low force of explosion. Tensile breakage in cone toward free face. Vertex of cone above explosion center. $C$, Increased force of explosion. Arc subtended by cones is larger. Vertex of cones coincides with explosion center. 


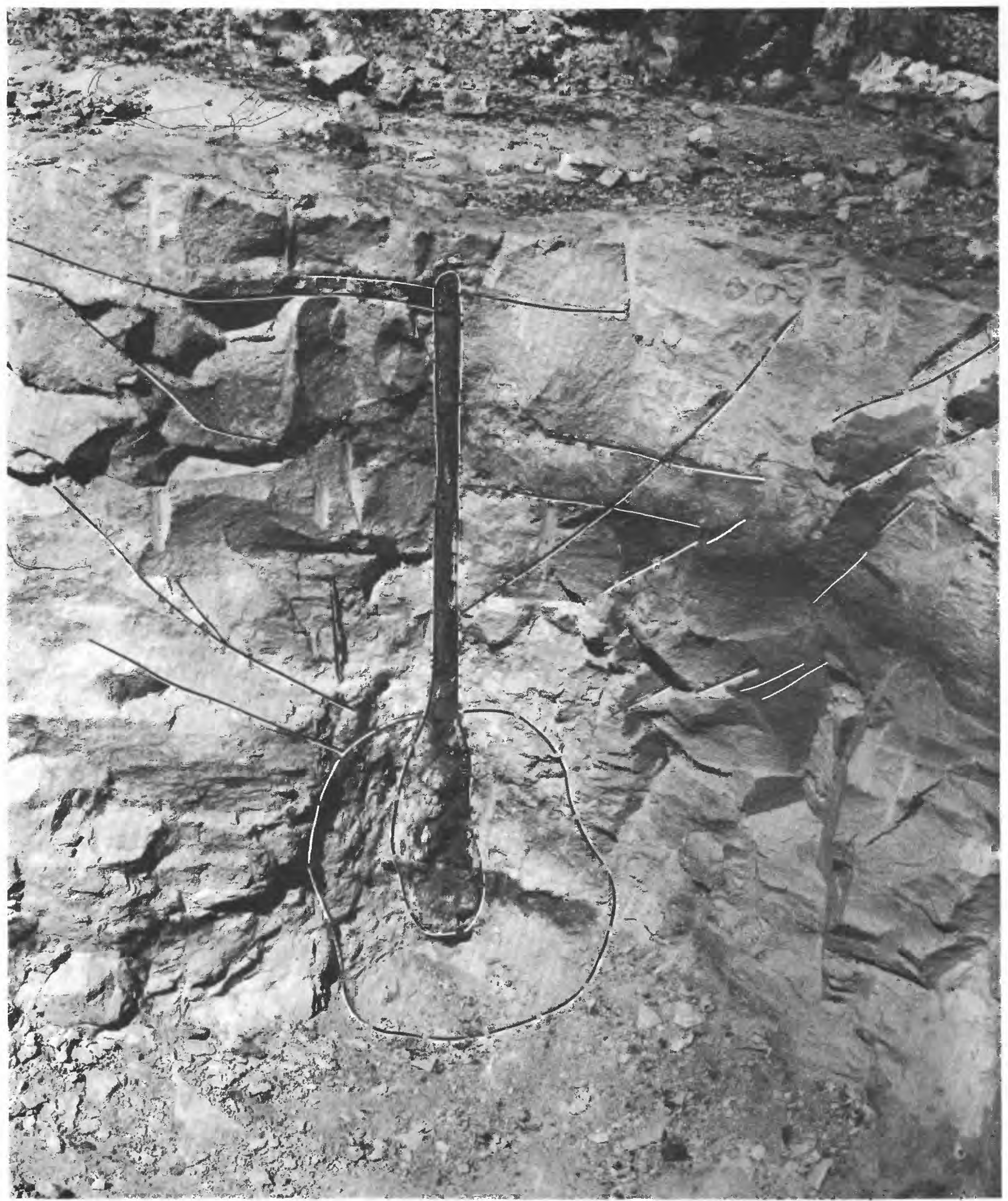

FIGURE 4.-Containment test 5A. Effects of contained explosion exposed by careful excavation. Drill hole was cemented tight after shooting to preserve shape. Rock immediately surrounding charge is granulated. Overlying rock contains radial hairline fractures and lifted bedding planes, but is otherwise undamaged. Note pencil to left of drill hole for scale. 
TABLE 1.-Tabulation of tests for containment of small explosive charges.

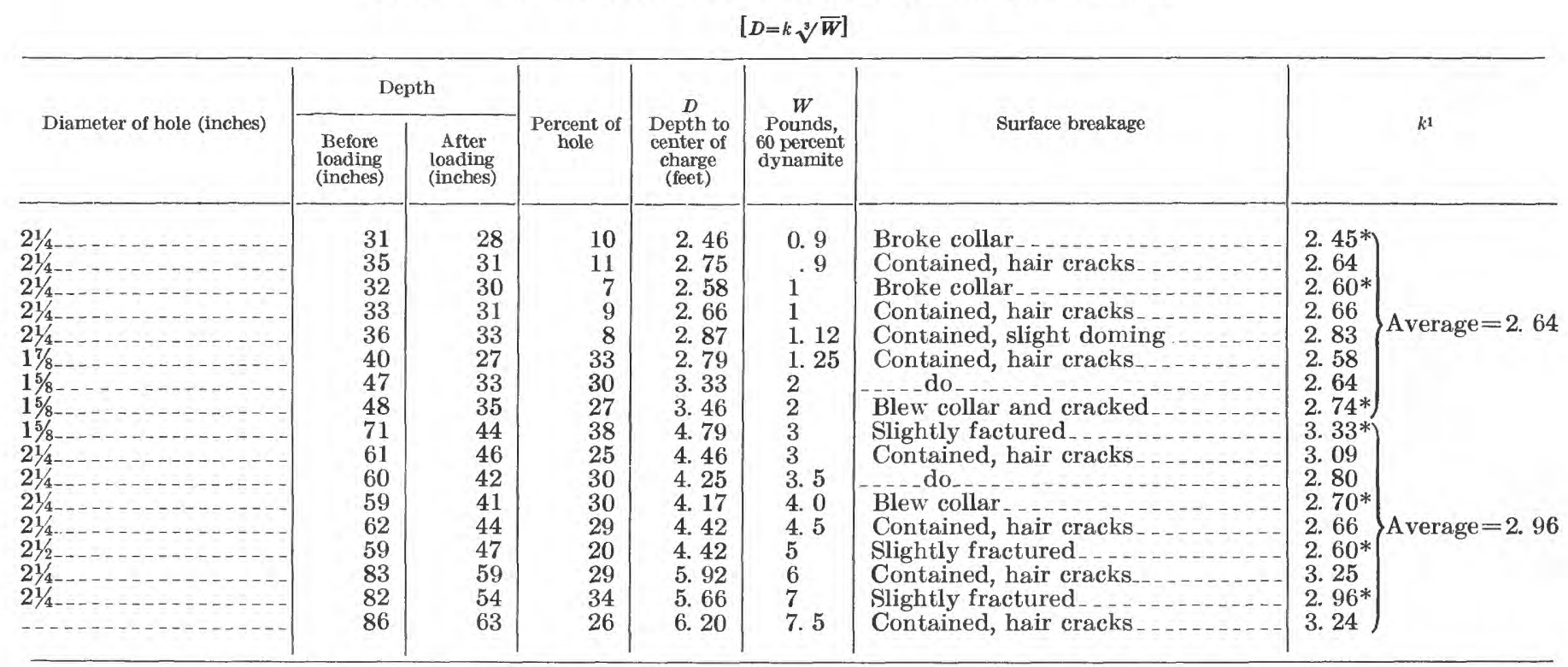

1 Values followed by asterisk indicate the surface breakage was slightly greater than true containment. A decrease in the amount of dynamite to that necessary for true containment will increase the value of $k$.

vertex of the cone above the shot point; in more fully energized explosions the vertex coincides with the shot point.

The first two categories were considered contained explosions. The third category, in which the rocks are fractured, does not represent true containment, for the openings from the shot chamber to the surface will permit the escape of fumes.

Table 1 is a tabulation of the results of the tests with 60 percent dynamite in which the surface effects were classed as incipient fracturing or slightly greater than incipient fracturing (indicated by an asterisk following the value of $k$ ). In table 1 the holes in which there was incipient fracturing give a range in the value of $k$ from 2.45 to 3.33 with an average of 2.81 . The numerical value of $k$ increases with the depth of the test hole. The average value of $k$ for holes from 2.5 to 4 feet was 2.64; for holes 4 to 7 feet it was 2.96. In these tests the increase of the numerical value of $k$ with the depth of the test hole indicates that the formula cannot be used satisfactorily without increasing the value of $k$ with increased depth. That is, $k$ is a variable.

It is known that in some rock lower strength dynamites will break more rock than higher strength dynamites. Some information on this behavior was gained from these tests. In a contained explosion the necessary thickness of cover was less for 40 percent dynamite than it was for 60 percent; but in these specific rocks when an explosion broke through to the surface, the broken area was relatively greater for 40 percent dynamite than for 60 percent.

\section{THE 10-TON EXPLOSION IN ROOM A}

\section{SURFACE EFFECTS}

On the afternoon of February 21, 1957, 10 tons of 60 -percent nitroglycerine gelatin dynamite was exploded in room $\mathrm{A}$. The entire area above room $\mathrm{A}$ was lifted several feet by the blast-visual estimates were as high as 10 feet. An instant later the surface fell back toward its original position. The precision surveys of Holmes and Narver indicate that a roughly oval area, covering about 3,700 square feet, was permanently raised 1 foot or more above its original position, and a subcircular area of nearly 12,000 square feet was lifted half a foot or more (fig. 5). The uplift-both transitory and permanent-was predominantly southwest of ground zero, chiefly because the shortest distance above the chamber to the ground surface was southwest of ground zero. Most of the rock breakage caused by the blast was in the southwest quadrant also.

An instant after the shot was detonated, a horizontally directed blast of gas, dust, and rock fragments emerged from the portal of the tunnel (fig. 6). The gas-dust cloud traveled hundreds of feet from the portal before it lost momentum and was dispersed into the atmosphere by the wind. Rock debris hurled from the tunnel by the blast was deposited in a narrow cone of dispersal fanning outward from the portal. Blocks of rock 1 foot in diameter were thrown 150 feet from the portal, although most of the material carried that far was smaller; small stones were thrown as far as 400 feet. The scatter pattern was narrow, well defined, and 


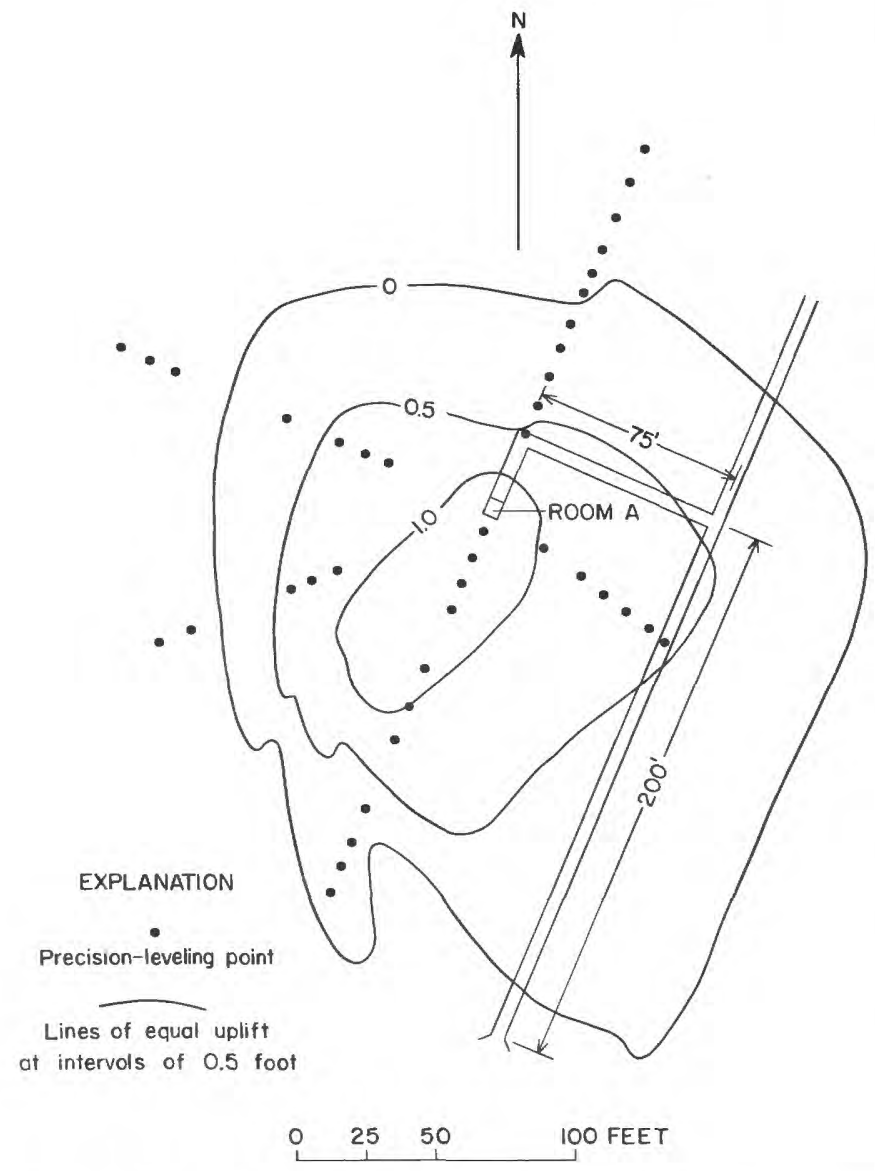

Figure 5.- Map showing permanent uplift resulting from 10-ton explosion as determined from precision leveling and inferences from fracture pattern, prepared by Ernest Dobrovolny.

remarkably clean cut, like a blast from a giant shotgun. Juniper trees partly in the trajectory of the cloud were stripped of leaves, bark, and branches on the side within the path but were left unmarked on the other side. A tree 75 feet from the portal was stripped clean, but a set of fuse boxes less than 1 foot away was undamaged. The escape of gas from the tunnel was due to partial destruction of one wall of the shot chamber by the explosion, which permitted the gas to bypass the stemming.

Preexisting planes of weakness exerted a strong influence on the surface pattern of fracturing caused by the blast; most of the breakage in fact, followed preexisting fractures, and the area of deformation was largely delimited by preexisting fractures. The extent and limits of fracturing are shown in figure 1. The greatest differential surface displacement followed a small preexisting fault due south of ground zero, and most of the severe fracturing was west of this fault; the west side of the fault was uplifted 10 inches vertically relative to the east side.
Deformation west of room A was restricted mostly to the area between ground zero and the northeasttrending fault 10 feet west of ground zero, but some breakage and lifting occurred along bedding planes west of the fault.

Deformation southwest of ground zero was largely restricted by the northwest-trending fault that passes up Portal Draw. This fault dips eastward. Again, however, minor fracturing and movement occurred to the west of the fault, mostly along old joints.

Deformation on the south was limited largely by the outcrop of bed 22a. The base of this bed served as a parting plane above which all overlying rocks were lifted upward by the blast and below which little or no surface deformation took place. That is, downslope from the outcrop of bed 22a, deformation was negligible. Several higher bedding planes also served as parting planes. Lifting extended eastward along the base of bed 22a to a point 57 feet southeast of the tunnel centerline where a strong preshot joint plane restricted further movement.

The most distant observed effects of the blast occurred about 310 feet south-southwest of the chamber where the ground opened slightly along the hanging wall of the same northeast fault that passes just west of ground zero. This opening appeared to be the result of ground vibration rather than differential movement across the opening.

The limits of deformation on the east are somewhat indefinite, owing probably to a lack of any nearby strong, continuous, or well-defined structural features that might have served to restrict the movement. Deformation north of ground-zero surface was negligible, chiefly because the ground surface rises rapidly in that direction, and the amount of cover above the shot chamber increases accordingly.

A small sand crater caused apparently by escaping gas was formed 150 feet south by west of the shot chamber at the junction of bed 22a and the fault in Portal Draw. For several hours gas "bubbles" rose through the fine dust that formed the bottom and lips of the crater, and a strong odor of gas remained at the crater 24 hours after the test.

\section{UNDERGROUND EFFECTS}

The dynamite used in the 10-ton and 50-ton tests was packaged in 50-pound cartridges. The specified dimensions of room $\mathrm{A}, 5$ by 8 by 8 feet, had been calculated as the size necessary to hold the 10-ton charge. Irregularities of the floor and walls prevented completely orderly stacking of the dynamite cartridges, and the charge as finally loaded extended 1.5 feet into the entrance lateral. Primacord, selected as the safest and 

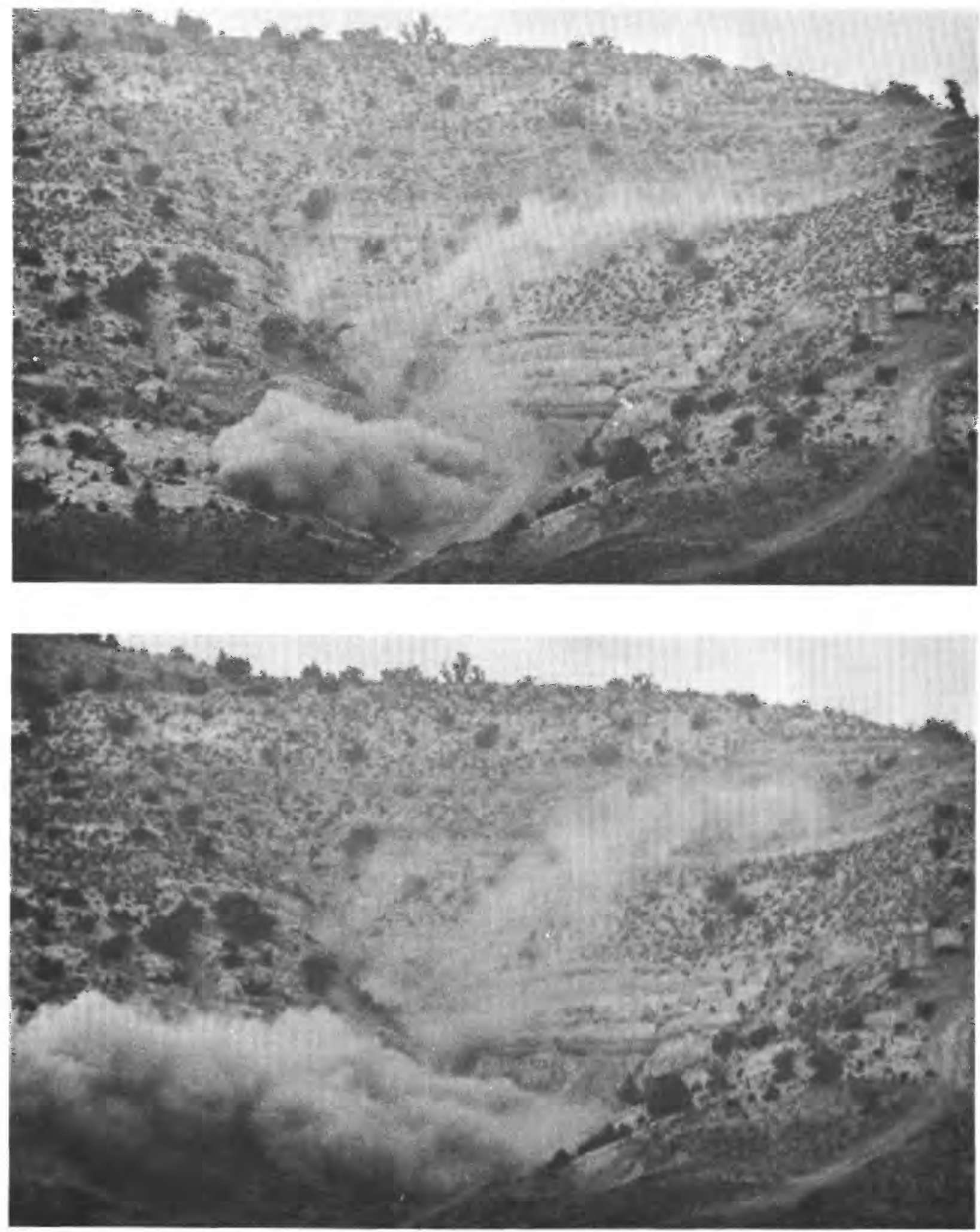

Figure 6. - Jetlike dust cloud emerging from tunnel after 10-ton explosion. Escape of gas from tunnel was due to partial destruction of one wall of shot chamber, which permitted gas to bypass stemming. Upper view, about 0.7 second after detonation; front of cloud at left is traveling about 380 feet per second. Lower view, about 2 seconds after detonation; forward momentum is diminished. Note dust rising from fractures in hillside above chamber. High-speed photographs by Edgerton, Germeshausen \& Grier, Inc. 
HIGH-EXPLOSIVE TESTS, USGS TUNNEL AREA, NEVADA TEST SITE

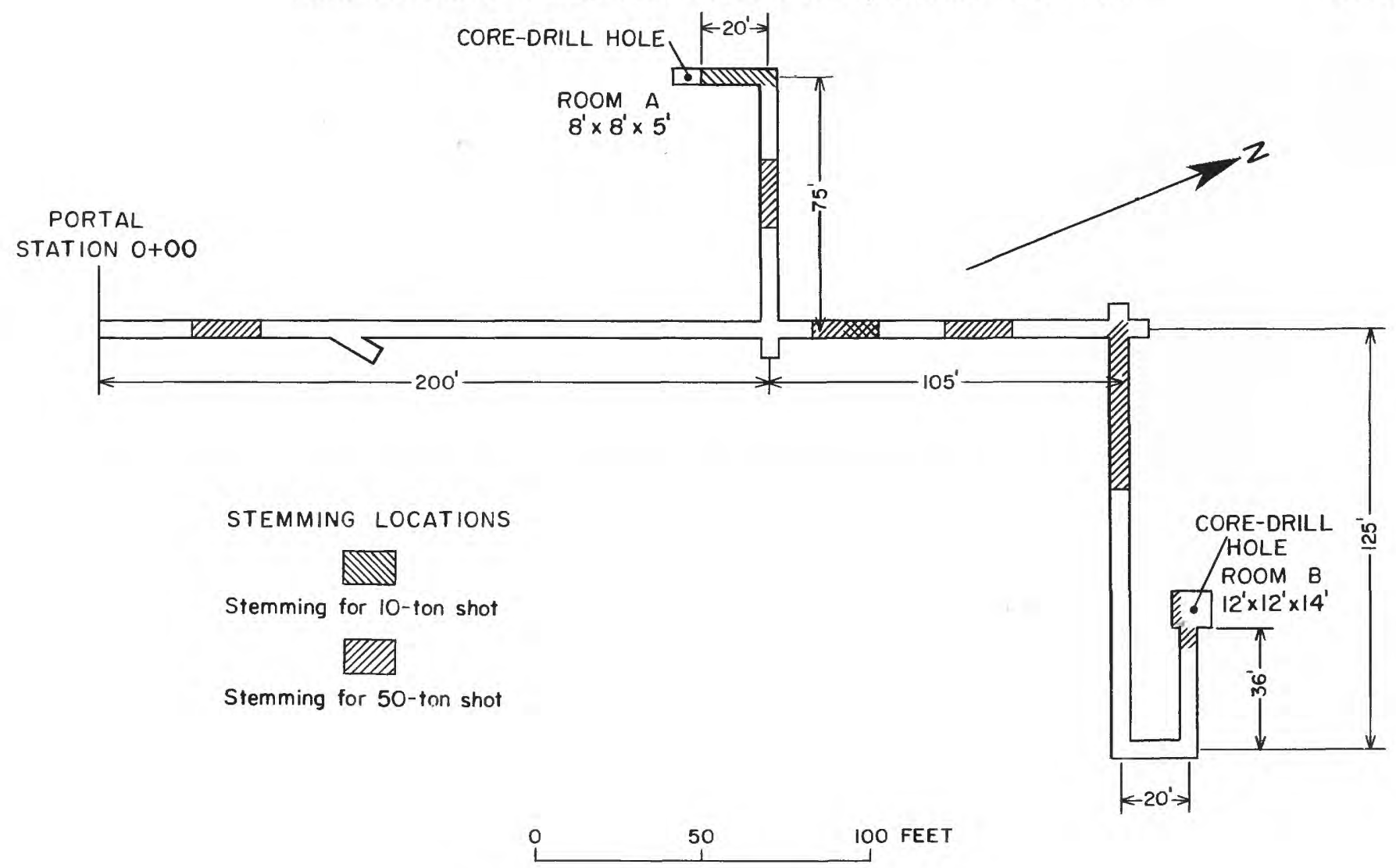

FIGURE 7.-Map of USGS Tunnel showing stemming.

most efficient means of detonation, was laced through each layer of cartridges and branch lines were run to the portal where they were connected to electric detonators in a remote-control circuit.

The entrance lateral to room $A$, from the dynamite charge to the north wall of station $2+75 \mathrm{~W}$., was stemmed tightly with sandbags (fig. 7), and a sandbag barrier was also placed in the main tunnel between stations $2+30$ and $2+35$ to protect the workings to room B. The bags were filled with finely crushed limestone aggregate from a deposit 35 miles away in Frenchman Flat.

After the 10-ton blast a dangerous concentration of carbon monoxide was indicated in the workings by the National Bureau of Standards colorimetric detector. The tunnel, therefore, was ventilated for 2 days before cleanup work was started.

The main tunnel between the portal and the sandbag barrier at station $2+30$ was choked with more than 200 cubic yards of debris (pl. 6). This muck increased in depth from about 6 inches at the portal to an average of 5 feet (fig. 8) at station $2+00$ and beyond to the sandbag barrier at station $2+30$. On first examination there appeared to be a sorting of the muck-fines in some sections of the tunnel alternating with coarse $6350730-62-3$ material in other sections. Remapping, however, showed that the bulk of the coarse material, particularly that of boulder size, had spalled from the walls or back fairly close to its place of repose. The west lateral was swept clean of all fine material, but it contained large boulders that had been blown out of the explosion cavity.

After the main tunnel was cleared of debris and the west lateral reopened, it was found that the stemming had not failed, but that the wall between the room and the lateral had failed between stations $2+48 \mathrm{~W}$. and $2+59 \mathrm{~W}$. In the failure of this wall, a triangular block of rock that had been the southeast wall at station $2+75 \mathrm{~W}$. was blown across the old west lateral, completely blocking it and leaving the new opening to the east. This block was fractured internally; but, as shown by bedding planes, its attitude was normal and there was little or no jumbling of the component parts. Glide surfaces at the top and base of the block correspond roughly to bedding planes and are marked as crushed and sheared zones from $1 / 2$ to 2 inches thick. Slickensides and fluting on the glide surfaces indicate that the direction of movement was N. $62^{\circ} \mathrm{E}$. A zone of crushed rubble 4 to 6 inches wide separated the block and the north wall of the lateral. 

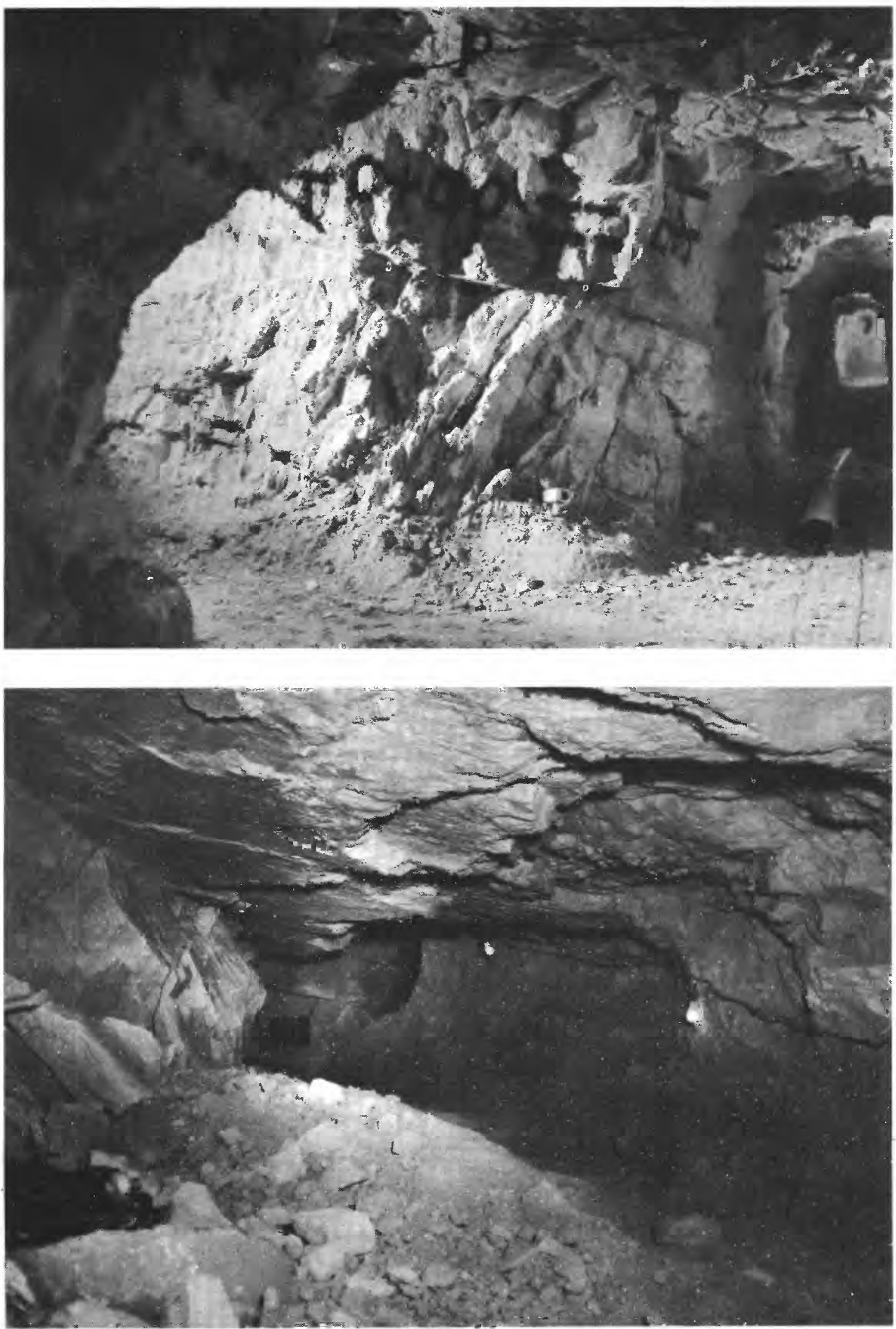

FIGURe 8.-Views north in the main tunnel at station $2+00$ before (above) and after (below) the 10-ton explosion in room A. Opposite the lateral tunnel in lower view, the main tunnel is nearly closed by debris blown from room A; most of the coarse material in foreground, however, dropped from the back. 
Until excavation had provided evidence to the contrary, it was generally believed that the sandibag stemming in the entry to room $\mathbf{A}$ had failed and that much of the solid matter in the jetlike cloud driven from the portal an instant after the explosion was provided by the sandbag filling. In later excavation, however, most of the sandbag stemming was found intact, though modified (figs. 9, 11). Subjected to extreme pressures, the material in the sandbags-loose sand-sized particles of limestone, quartz grains, and a minor amount of tufi-had been driven together to form a compact, hard, artificial rock. This artificial rock has moderate strength, but once broken, it crumbles into discrete grains. R. E. Wilcox (written communication, 1957), of the U.S. Geological Survey, who studied the material under the petrographic microscope, reported as follows:

The material in thin section is seen to be about 75 percent limestone fragments of all sizes up to $3 \mathrm{~mm}$ in diameter, the larger ones being rounded. Grain size of the limestone is variable but many pieces are much finer gxained on their rims, and interstitial carbonate is likewise very fine grained. The noncarbonate fraction is composed of rock and crystal fragments. Rock fragments are spherulitic obsidian, arkose, and chert. Crystal fragments are quartz, alkali feldspar and plagioclase, all much shattered and strained where in groups, less fractured where isolated in carbonate zones. (Freed from the matrix, most quartz and feldspar crystals disintegrate into tiny fragments upon slight pressure of a needle point under the binocular microscope. Crystals from the raw material source are clear and strong.) It is estimated that there is less than 5 percent of clay mineral present.

The coherency of this aggregate can probably be ascribed to the compressive granulation and flow of the limestone fragments without fusion. I do not believe the clay fraction was a significant "bonding" agent here.

Fissures, cracks, crushed zones, and renewed movement along old joints in the west lateral and in some parts of the main tunnel resulted from the explosive forces (pl. 3). In the main tunnel most of the fractures caused by the explosion are open fissures that range in width from less than 1 inch to about 5 inches. No damage was observed beyond the fault at station $2+65$ in the main tunnel. In the main tunnel from station $1+65$ to station $2+00$ and in the west lateral from station $2+00$ to station $2+16 \mathrm{~W}$., the back of the tunnel broke out cleanly to the bedding plane between beds 21 and 22a; the block above this bedding plane was shifted laterally about 0.8 foot relative to the walls below.

In the west lateral from station $2+18 \mathrm{~W}$. to station $2+40 \mathrm{~W}$., the south wall was pushed northward into the lateral. The maximum displacement was at station $2+23 \mathrm{~W}$. where the reestablished centerline of the preshot lateral passed though the postshot south wall.

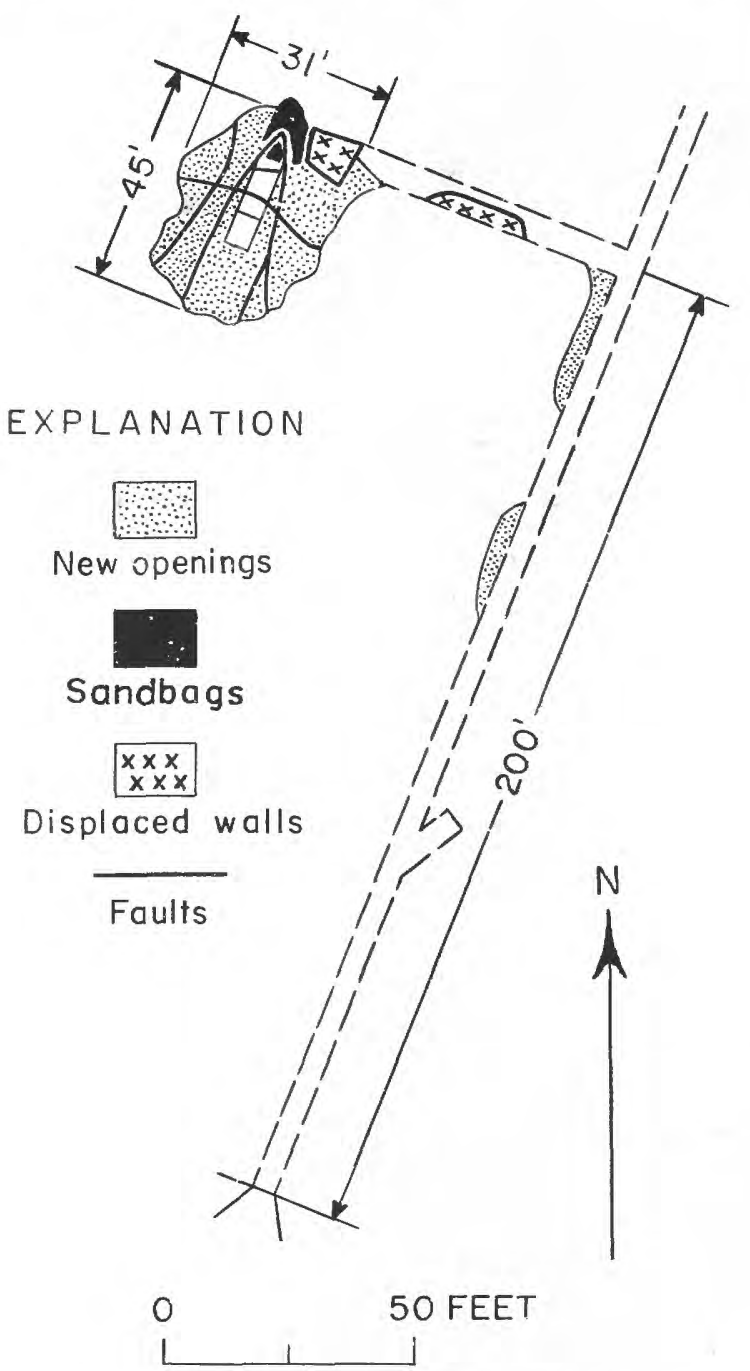

FigUre 9.-Underground effect of 10-ton explosion.

The eastern boundary of the displaced wall is a zone of fractures open about $1 / 4$ to $1 / 2$ inch. The western boundary is brecciated, but it contains very few open fractures. Parallel to, and about a foot north of, the centerline along this displaced wall, the back of the postshot lateral forms a sharp peak; the rock along the peak is minutely fractured.

The explosion opened room $\mathbf{A}$ from its original 5 by 8 by 8 feet to a large roughly rectangular chamber 45 feet long, 31 feet wide, and 26 feet high above the original grade line (figs. 9-11). The volume of this chamber is about 1,100 cubic yards. When the chamber was first reentered, it was slightly more than half full of muck. Later excavation of the north end of the chamber proved, by the order in which the different rock types were stacked from grade upward, that this muck had dropped from the back after the explosion had formed the expanded cavity (fig. 10). 


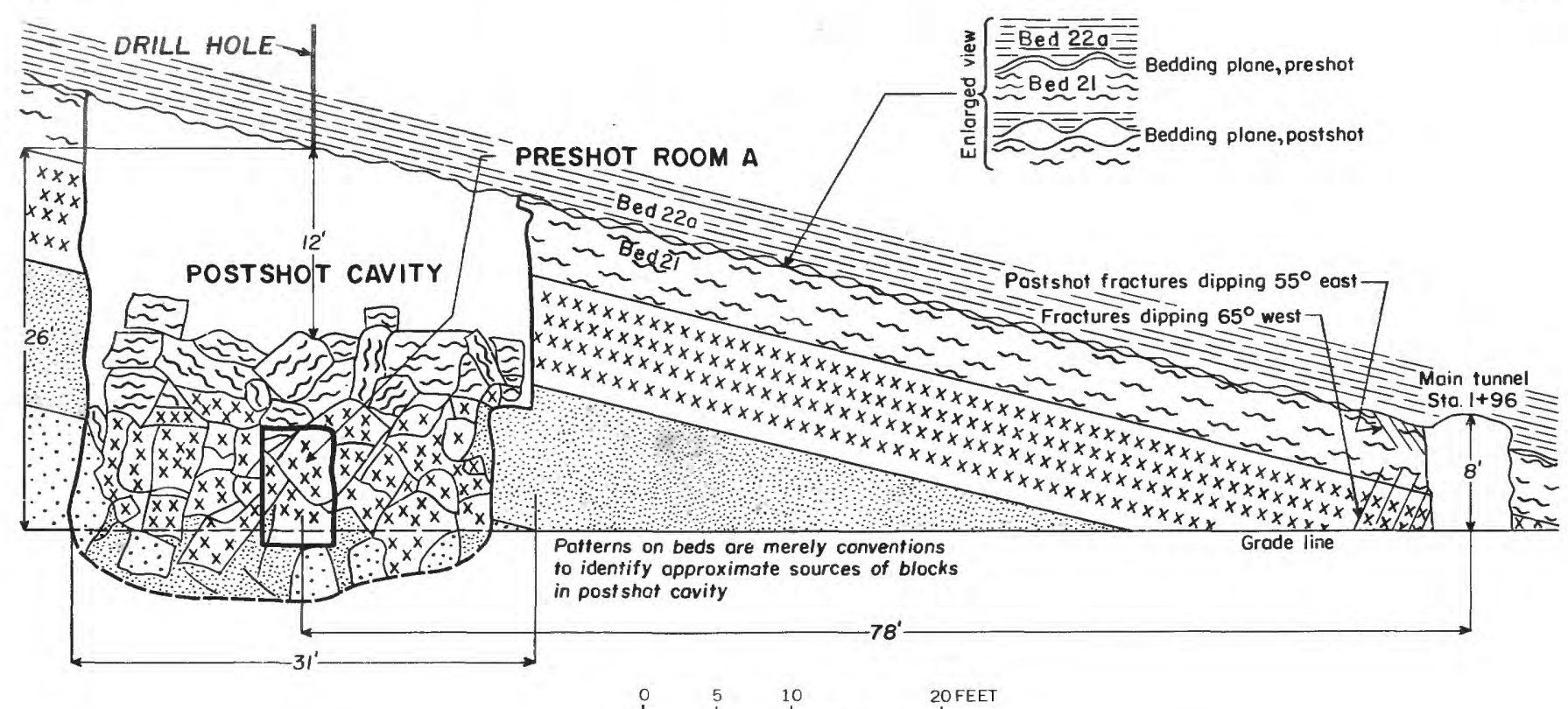

FrguRe 10.-Diagrammatic cross section through postshot cavity after 10-ton explosion.

The walls of the postshot chamber are almost vertical, although they are irregular in plan (fig. 9). The back of the chamber (fig. 11), formed of the base of bed 22a, was faulted and fissured by the explosion. Three north-northeast-trending faults in the back, one on the east and two on the west, bound a triangular mass of rock that was driven upward like a wedge (pl. 3). The fault on the east of this triangular block has maximum displacement of 2.5 feet near the center of the room; the two on the west have maximum displacement of 0.7 foot. The displacements on these faults diminish rapidly towards the walls of the chamber. A fissure open 3 to 5 inches crosses the center of the back from east to west. Vertical open fissures in the east and west wall are apparently counterparts of the open fissure in the back. However, the fissure in the east wall is about 2 feet north of the one in the back, and the one in the west wall is 7 feet south of alinement. These offsets between fissures in the walls and back are more evidence of the independent action of the block above bed 21.

All evidence, both underground and surface, indicates that the bedding plane between beds 21 and $22 \mathrm{a}$ was a major zone of weakness with respect to both shock waves and gas pressures generated by the explosion. A large block of rock between this bedding plane and the surface was raised and slightly shifted by the explosion. The approximate surface boundaries of the block are the fault south of room A, the outcrop of the bedding plane near the portal, and the fault that follows Portal Draw to a point nearly over room A. Within the tunnel at station $2+00$, in the back of the explosion chamber $\mathrm{A}$, and in the cliff above the tunnel portal crenulations along this horizon are displaced so that some of the troughs in the overlying bed $22 \mathrm{a}$ rest on the crests of the crenulations on bed 21 (fig. 10). In the southwest wall at station $1+95$ the upper 1.5 feet of bed 21 was fractured and spalled (fig. 12). These fractures dip $55^{\circ}$ eastward and are fluted or slickensided in direction of dip. Immediately below these east-dipping fractures, other fractures dip $65^{\circ}$ westward. The angle between the two sets of fractures indicates that these are shear fractures caused by the weight of the uplifted block as it dropped back after the explosion.

The disposition of the rock that originally filled the explosion chamber is accurately known in part only. With due consideration for the fact that broken rock occupies at least 1.33 the volume it occupied before breakage, the explosion chamber (less the volume of original room A) contributed about 1,400 cubic yards of broken rock. Of this amount only 800 cubic yards are readily accounted for by the 600 cubic yards that remained in the lower part of the explosion chamber and 200 cubic yards distributed along the main tunnel.

Inferences concerning the disposition of the remaining 600 cubic yards can be made, but each possibility must be thoughtfully qualified. The precision surveys over the explosion chamber indicate that a roughly oval area is domed upward-the volume of this domed area is about 600 cubic yards greater than the preshot volume. However, a large proportion of this perma- 


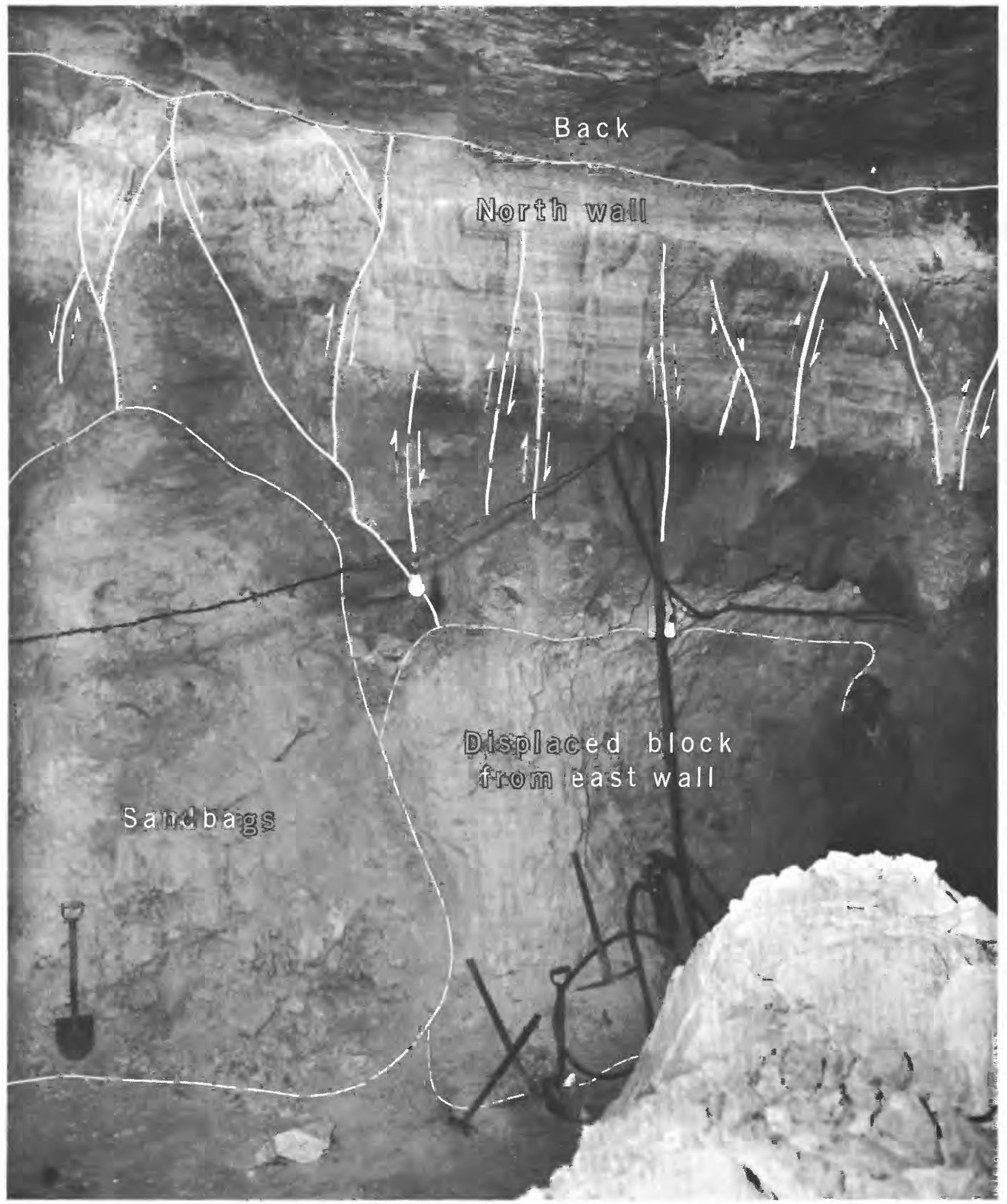

FIGURE 11.- North wall of room A after 10-ton explosion. Former entry to room is blocked by solid rock, lower center; miner is standing in new entry, lower right. Former height of room was about the same as that of new entry. Sandbag stemming on left remains intact. Small faults in north wall terminate against back. Note upward-driven wedge of rock above sandbags. 
nent updoming must be attributed to the volumetric increase of rock upon breakage. Moreover, the fissures resulting from the explosion are open and are not muck filled. The rock surrounding the shot point was distended radially outward. Reference points, such as core-drill holes, station locations, joints, bedding planes, and lithology indicate that the radial outward movement retained after the blast is in terms of inches, and can account for only a few tens of cubic yards.

The dust cloud that issued from the tunnel carried an indeterminable amount of material. The gas from the explosion, at high pressure, reached high velocities within the confinement of the tunnel. Broken rock, from dust to cobble in size, was carried suspended in the high velocity gas stream. Outside the confinement of the tunnel a turbulent column of air was driven by its own momentum and by the pressure of the gas behind. With the decrease in velocity of the gas stream, the larger rock particles were no longer suspended but assumed the free-flight properties of projectiles. The dispersal cone formed of these rock fragments was 300 to 400 feet long, 50 to 70 feet wide, and from 6 inches deep at the apex of the cone near the portal to a scattered veneer at the base of the cone. The fine dustsized particles of rock were suspended in the turbulent column of air and were carried off by the wind.

To check the possibility that the loss might be attributable to compression resulting in increased density of the wallrocks, with consequent decrease in pore space, two pairs of samples were taken from recognizable lithologic horizons. One sample from each pair came from close to the chamber, the other from the same horizon at a considerable distance. The bulk specific gravities of these samples were as follows:

$\begin{array}{lrlr}\text { Sample } & \text { Adjacent } & \text { Sample } & \text { Distant } \\ 1 & 1.40 & 1 a_{-} & 1.356 \\ 2 & 1.69 & 2 a_{-} & 1.78\end{array}$

It will be noted that the density of sample 1 is higher than sample $1 \mathrm{a}$, whereas sample 2 is lower than $2 \mathrm{a}$. The likely explanation is that the material of sample 1 was cohesive and retained the increased density imposed by the explosion. In sample 2, minute fractures opened on rebound after the explosion, resulting in a lower density. If these results can be considered diagnostic, volumetric decrease in some lithologic units would tend to be canceled out by increase in other lithologic units.

The estimated volume ( and tonnage) of rock broken and displaced by the 10-ton explosion is an irregularshaped block of 38,500 cubic yards ( 54,000 tons). Three weeks after the explosion the temperature in the explosion chamber was $73^{\circ} \mathrm{F}$. The ambient temperature in the tunnel was $54^{\circ}$ to $57^{\circ}$.

\section{THE 50-TON EXPLOSION IN ROOM B}

\section{SURFACE EFFECTS}

On the morning of April 5, 1957, 50 tons of 60-percent nitroglycerin gelatin dynamite was exploded in room B. The area over the chamber was lifted sharply by the blast (fig. 13). High-speed photographs taken at the time by Edgerton, Germeshausen, \& Grier, Inc., AEC technical contractors, indicate that a maximum uplift of about 26 feet occurred over ground zero 0.7 of a second after the explosive was detonated. Most of the doming was within a radius of about 100 feet of ground zero, but appreciable uplift and severe fracturing occurred as distant as 525 feet from ground zero. An instant after the blast the ground surface fell back and the present fracture pattern became fixed. As the ground surface fell back, a low dust cloud spread blanketlike over the hilltop, temporarily obscuring ground zero. The extent and limits of fracturing and permanent updoming are shown on plate 5 .

\section{SURFACE FRACTURING}

As with the room A explosion, most of the major displacements were along preexisting fractures in the rocks, but in contrast with the room A explosion, many new strong fractures were formed within previously sound rock. The fracture pattern caused by the blast is mainly radial and focuses at the surface near ground zero. But it is modified by preexisting fractures along which renewed movement or dilatation occurred and by the effects of differential cover above room B owing to the topography. Fracturing was relatively light in the northwest quadrant of the blast area because of higher ground and hence greater thickness of rock cover in that direction. The severest fracturing was eastward from ground zero within a radius of about 100 feet of ground zero.

Pronounced radial fracturing occurred mostly in the area within 200 feet of ground zero where the surface was strongly distended by the updoming caused by the blast (pl. 5). Beyond 200 feet most of the breakage followed preexisting planes of weakness in the rocks, such as faults, joints, and bedding planes. Such planes of weakness served to outline the entire disturbed area, except for a relatively few outlying fractures.

In plan the disturbed area is roughly triangular with a base facing east and an apex pointing west (pl. 5). The length of the base is about 600 feet, the distance from base to apex is about 360 feet, and the area within the disturbed triangle is about 12,000 square yards. Severest breakage and strongest uplift are near the north corner of the triangle, near ground zero. Again, minor effects and some fracturing occurred outside the 


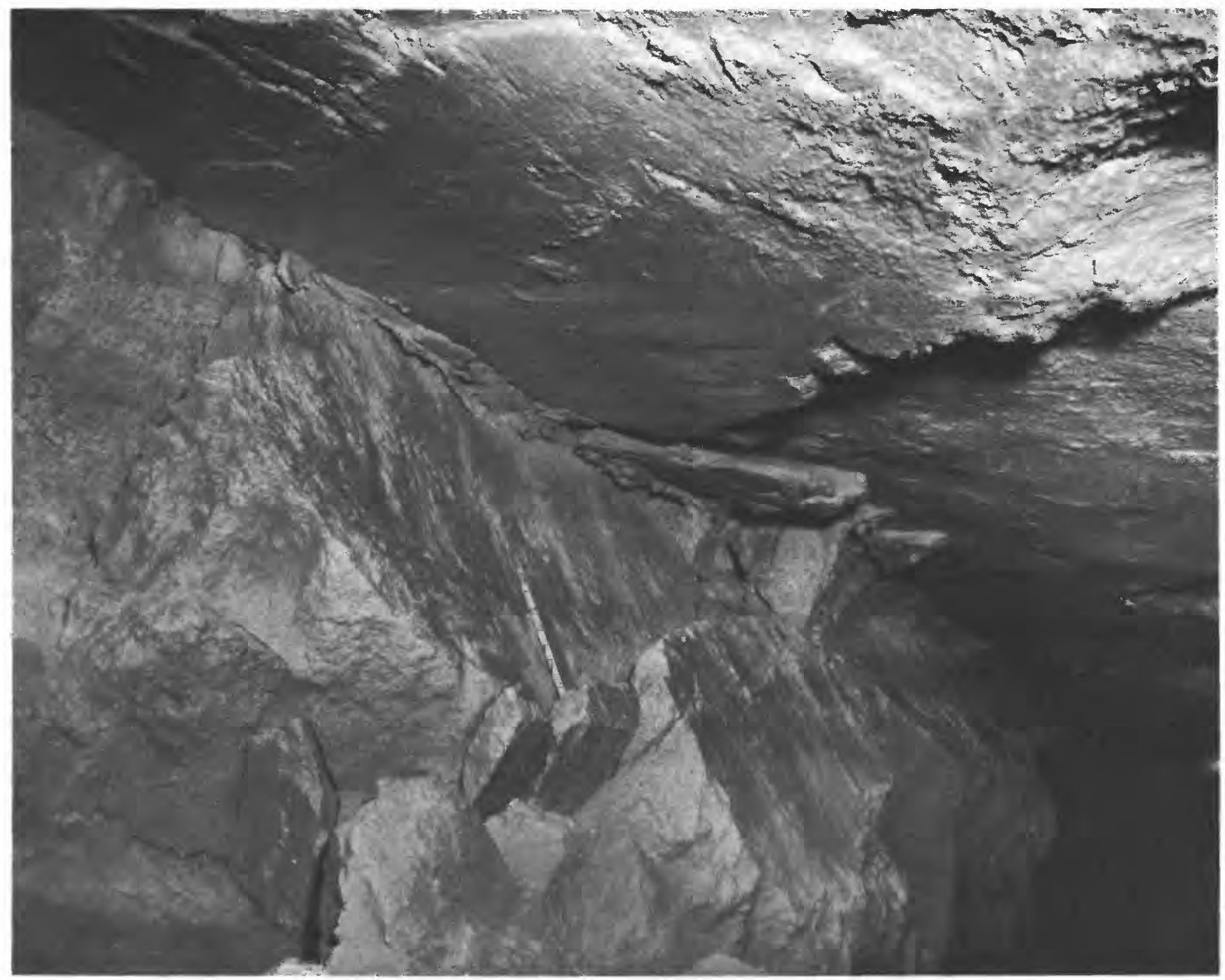

FIGUR 12.-Slickensides on back of main tunnel near station $1+95$ after 10 -ton explosion, caused by slippage on bedding plane between back and west wall. Blast pushed west wall to right relative to back: rock above back was lifted and dropped, causing high-angle slickensided shears to form in west wall below. Ruler near center of picture lies against a shear plane. Original west wall has spalled away.

triangle, but the most notable effects are within. The broad base of the triangle, on the east, is formed of a near-continuous fracture or zone of fractures mainly along a preexisting west-dipping fault; the apex of the triangle is at the intersection of two faults southwest of room A which underwent movement when the charge in room $\mathrm{A}$ was detonated and underwent renewed movement when the charge in room B was detonated. During both explosions these faults largely limited deformation on the west. The southwest side of the triangle is marked by a zone of bedding-plane breaks shown at the ground surface by open fractures along bedding planes or by low scarps in the overburden; the northwest side of the triangle is defined by discontinuous open fractures that dip steeply toward the southeast.

Relative to the surrounding hillside, the triangular area defined above was lifted upward and pushed southward by the force of the explosion. Differential horizontal displacement is especially pronounced along the fault that bounds the triangle on the east where sets of en echelon tension fractures were produced by horizontally directed couples. Along the lifted bedding planes that bound the triangle on the southwest, the rock above the break overrode the rock below horizontally and in a southerly direction. Strong differential horizontal movement also occurred within the triangular area itself, and outside the immediate intensely fractured vicinity of ground zero the greatest accumulative displacement was along a series of south-trending fractures due south of ground zero. Along each of these fractures, the west side moved up and southward relative to the east side. (See pl. 5.) 

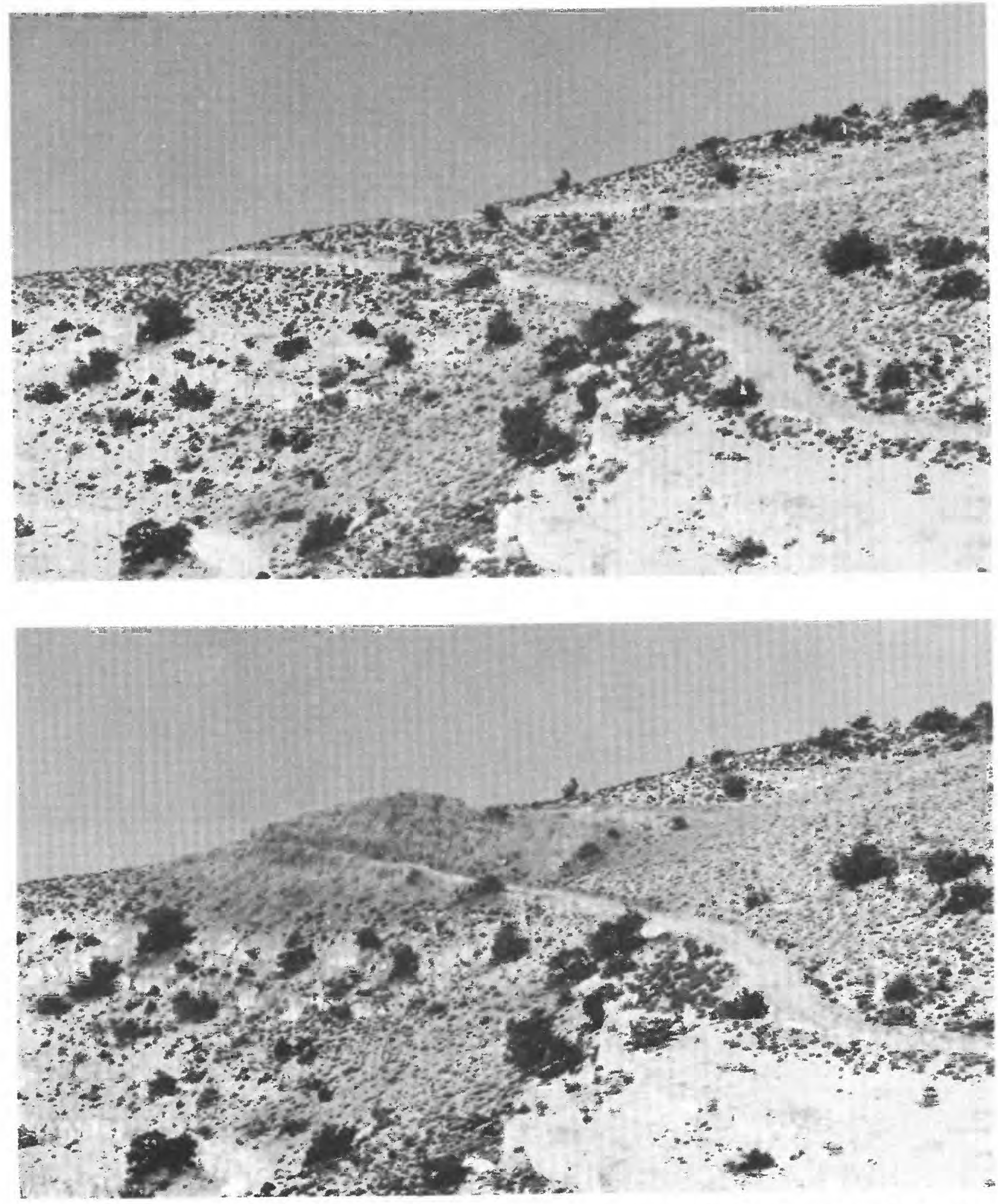

Fig 13 - S explosion. Top view, shortly before blast; bottom view, at peak of uplift 0.7 second after detonation. Hill at ground zero was lifted about 26 feet, High-speed photographs by Edgerton, Germeshausen, \& Grier, Ine. 


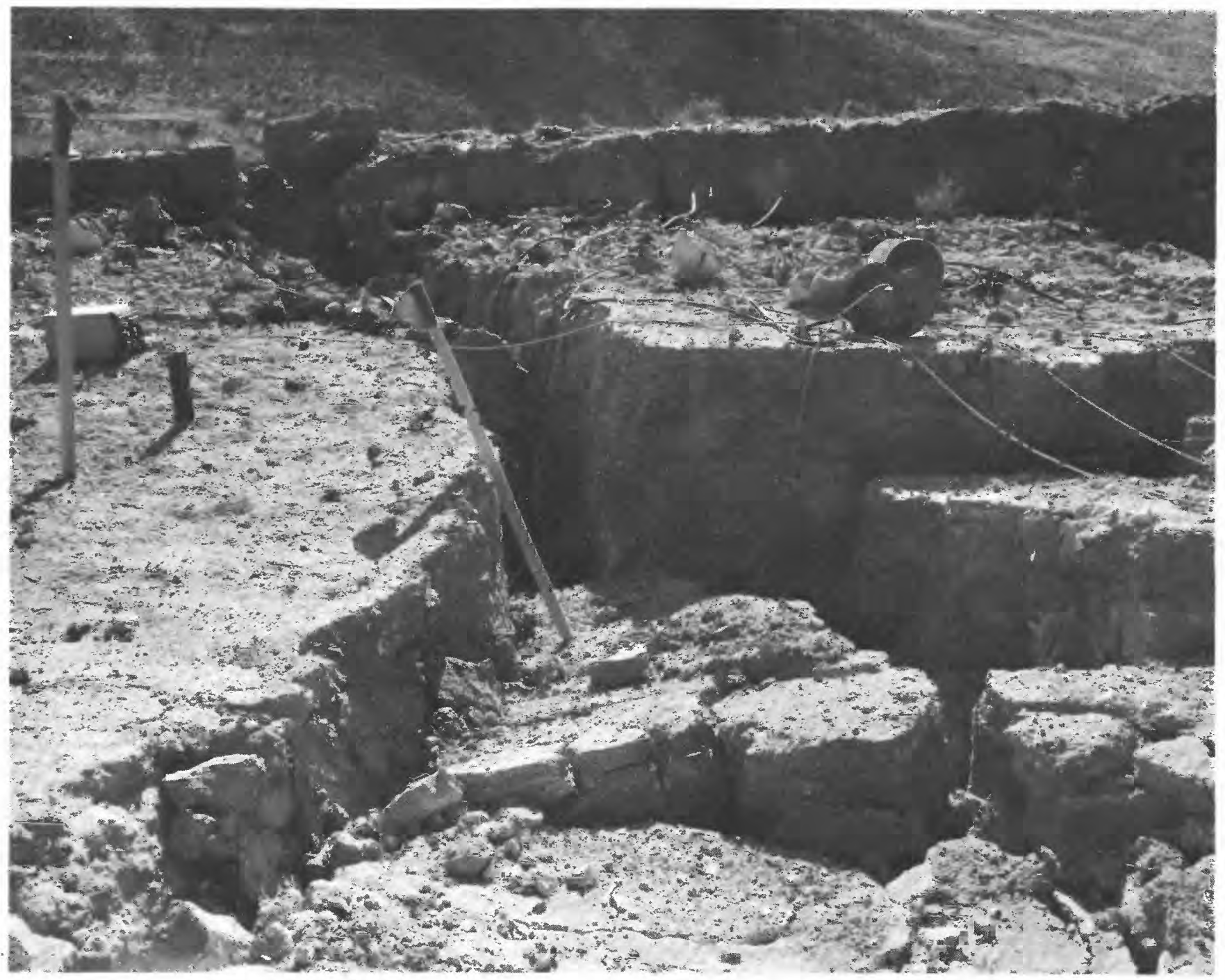

Figure 14.-Large fractures just north of ground zero, 50-ton blast. Some of these openings are more than 2 feet across. Dynamite fumes issued from these openings for several days after the blast.

In the intensely fractured area near ground zero (figs. 14-16) the present fracture and displacement pattern is the composite result of the movement and breakage that accompanied updoming at the instant of the explosion and the gravitative collapse that immediately followed. The greatest single displacement is along an old northward-trending fracture 35 feet east of ground zero (fig. 15). Before the explosion this fracture had had no apparent displacement at the ground surface, but underground it may have joined a small slip near station $3+05$. As a result of the blast, a surface scarp was formed along this fracture for a distance of about 200 feet, centering due southeast of ground zero where its displacement-upthrown on the east-is about 72 inches. From that point the displacement diminishes gradually northward and southward.

A second large scarp, also upthrown to the east and with a maximum displacement of nearly 3 feet, was formed along the old fault 10 feet west of ground zero. (This fault crosses the main tunnel at station $2+65$.) The scarp dies out gradually to the north. To the south, it ends rather abruptly in a maze of fractures in the old fault zone. The wedge-shaped area between the two large scarps, which contains ground zero, is less severely fractured than the area just to the east, but it contains exceptionally large openings - some as much as 4 feet across - and many grabenlike collapse features (fig. 16). Dynamite fumes issued from these openings for several days after the blast.

Most of the fractures caused by the 10-ton explosion in room $\mathrm{A}$ were further widened or otherwise modified by the 50-ton explosion in room B. One large fracture trending south from ground zero of room A, approximately along coordinate E. 646,770 had its relative 


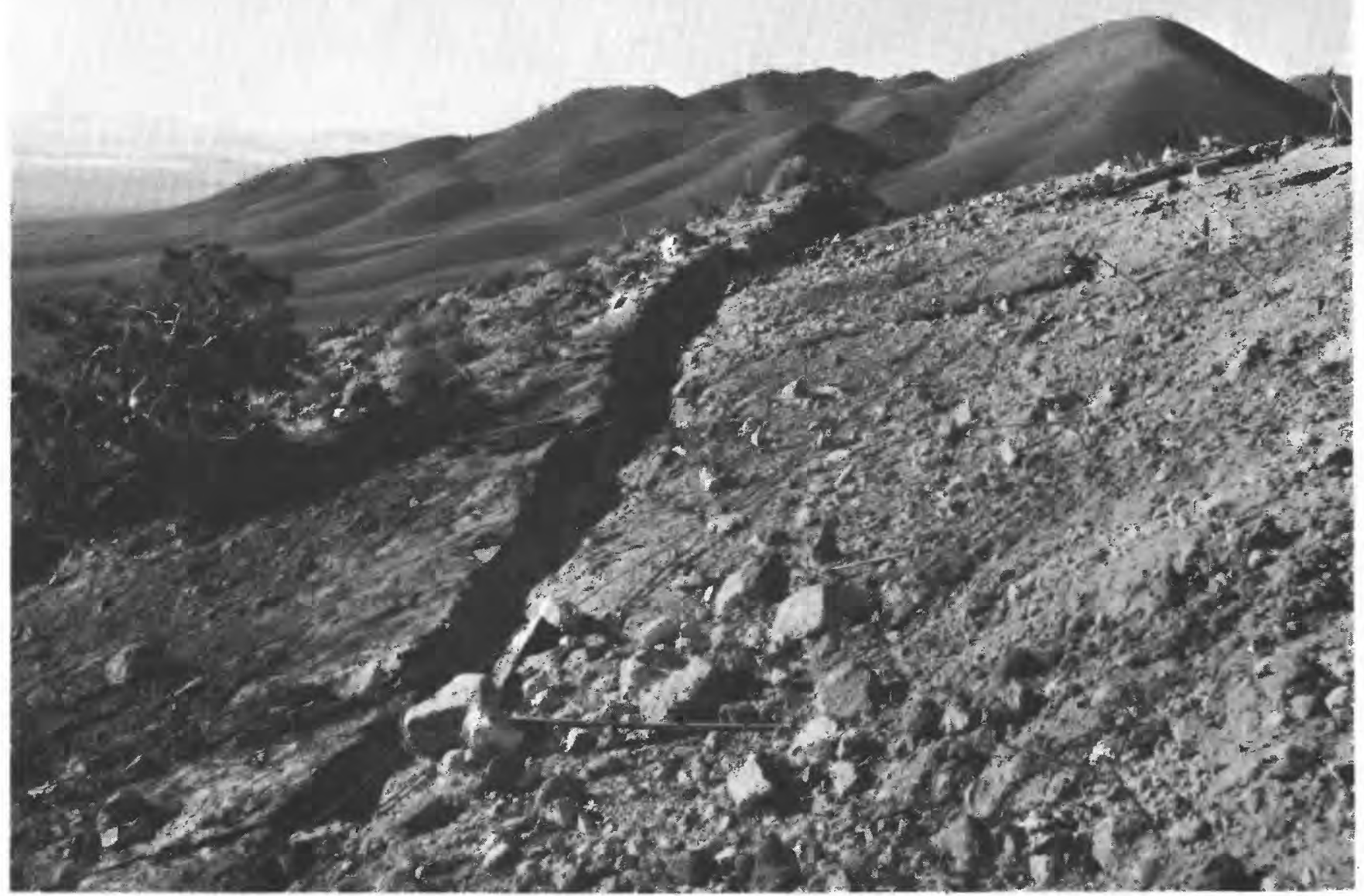

FIgUre 15.-Large northward-trending fracture 35 feet east of ground zero, 50 -ton blast. Maximum displacement along fracture is 60 inches. Maximum permanent uplift is 6 feet. This is an old fracture, but one that had no stratigraphic displacement before the explosion.

displacement reversed by the $B$ explosion. The west side of this fracture was uplifted by the $A$ explosion; the east side was uplifted by the $B$ explosion, which canceled out the displacement caused by the first blast. Renewed lifting occurred at the base of bed $22 \mathrm{a}$ in the tunnel portal area. Additional lifting occurred on the same bedding plane to the southeast, where there had been no movement previously, to a point where the bedding plane abuts at the surface against a conspicuous fault at grid point E. 646,910, N. 892,630. (This is the same fault that crops out 10 feet west of ground zero and crosses the tunnel at station $2+65$.) At the grid point above, the lifting crossed the fault and extended southeastward along a juxtaposed bedding plane in bed 19 (fig. 17). Bed 19 formed the back in room B before the explosion just as bed 21 had formed the back in room A. The surface scarp formed by the lifted bedding planes of beds 19 and 21 defines the southwest limit of the disturbed area and is one side of the triangle previously mentioned.

At grid point E. $646,930, N$. 892,460 , the lifted bedding plane in bed 19 abuts against the conspicuous preexisting west-dipping fault that served as an east and southeast boundary to the fractured area, the base of the triangle.

In addition to deep-seated fracturing, many sizable fragments of rock were spalled from the faces of ledges and low cliffs, apparently owing to rebound as the shock wave caused by the blast traveled to, and was reflected from, the ground surface. The most extensive breakage of this sort was in the portal area where part of the cliff face spalled off along an old but tight fracture (fig. 18). Boulders fallen from the cliff face damaged the portal to the extent that the cap timbers and lagging 


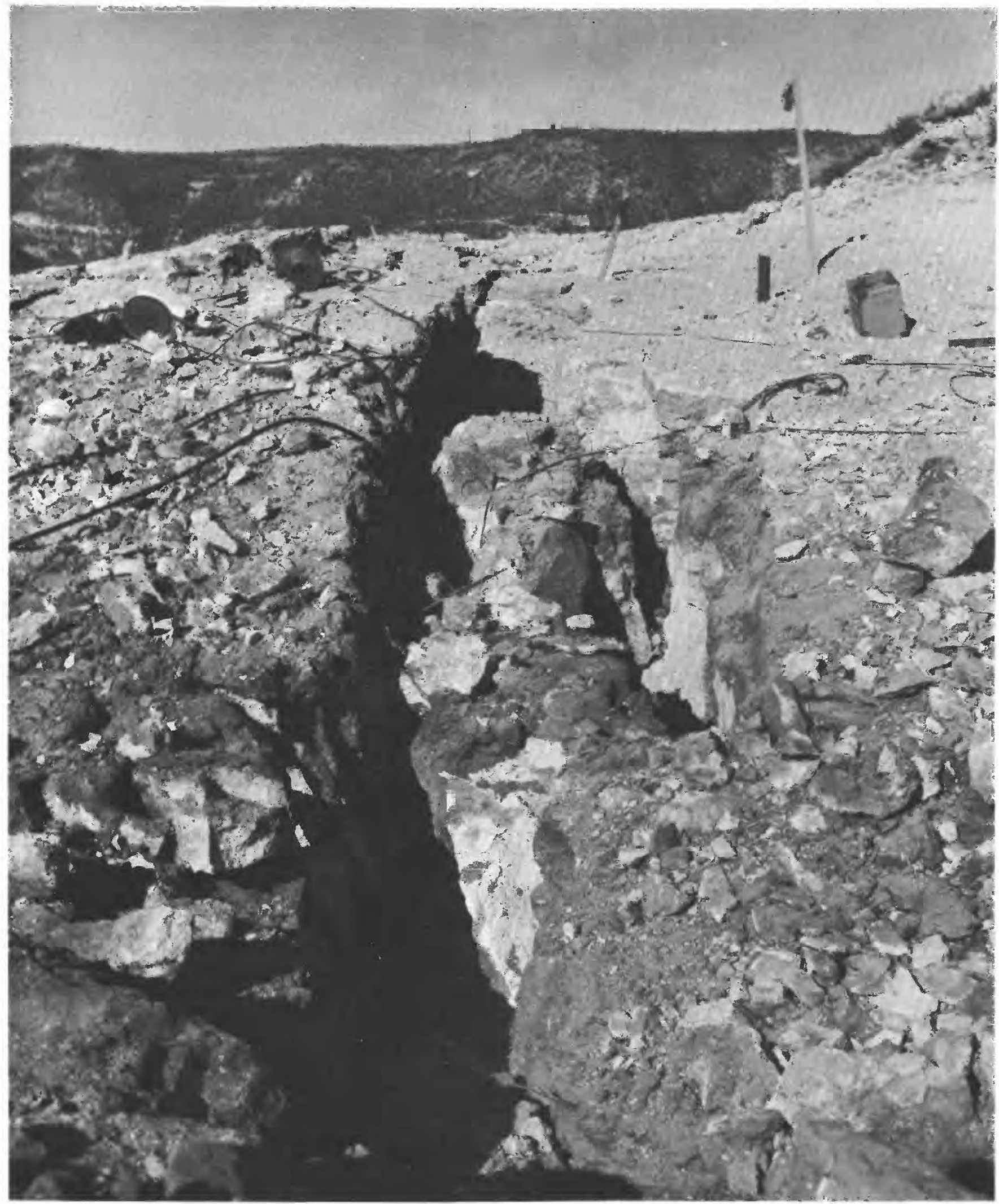

FIGURE 16.-View west toward ground zero (upper left behind spools), 50-ton explosion. Blocks in center of picture have dropped grabenlike into opening 4 feet wide. This part of hill lifted about 26 feet at instant of peak uplift; permanent uplift is about 4 feet. 


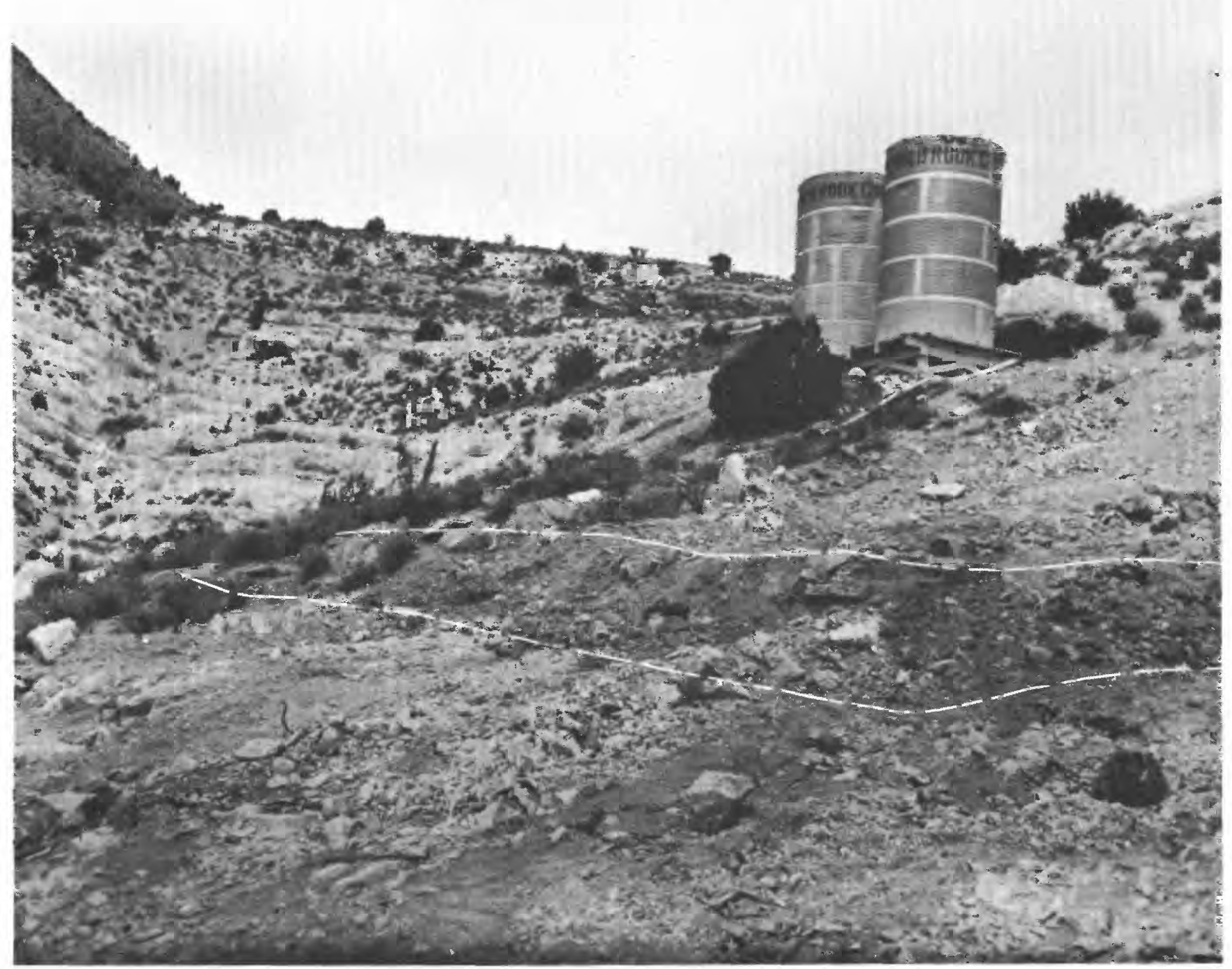

FIgurn 17.-Low scarp formed by shifting of bedding planes 500 feet south of room B, after 50 -ton explosion. Beds above scarp moved to left, overriding beds below. Large water tanks provided drill water and remained standing through the explosion.

had to be replaced, and boulders that dropped on the access road in Portal Draw were so large that secondary blasting was required before they could be handled by a bulldozer. Some of these boulders, before they were broken up with air hammers and dynamite, had estimated weights of 50 tons or more. Additional spalling of lesser magnitude was common on the east slope of the hill, 225 feet or so from ground zero. Impact marks were made on ledges hundreds of feet downslope in the amphitheatre by rolling boulders spalled from the east side of the hill.

\section{PERMANENT UPDOMING OVER ROOM B}

Lines of equal uplift over room B are shown on plate 5. These lines were drawn by combining the before and after precision-survey data of Holmes and
Narver with observed offsets and displacements of the ground surface above the explosion chamber. Precision surveys controlled both horizontally and vertically were run along eight traverse lines arranged radially from ground zero. The density of control points for drawing the lines of uplift, therefore, is high in the vicinity of ground zero, but drops off rapidly away from ground zero. Inasmuch as the average number of control points per unit area is inversely proportional to the square of the distance from ground zero, the accuracy of the contouring diminishes proportionately away from ground zero. Had the control been set up on a grid system, the accuracy would have been uniform throughout the area. The chief advantage of the radial control system used is that the greatest number of control points occur in the central area where the displacement was 

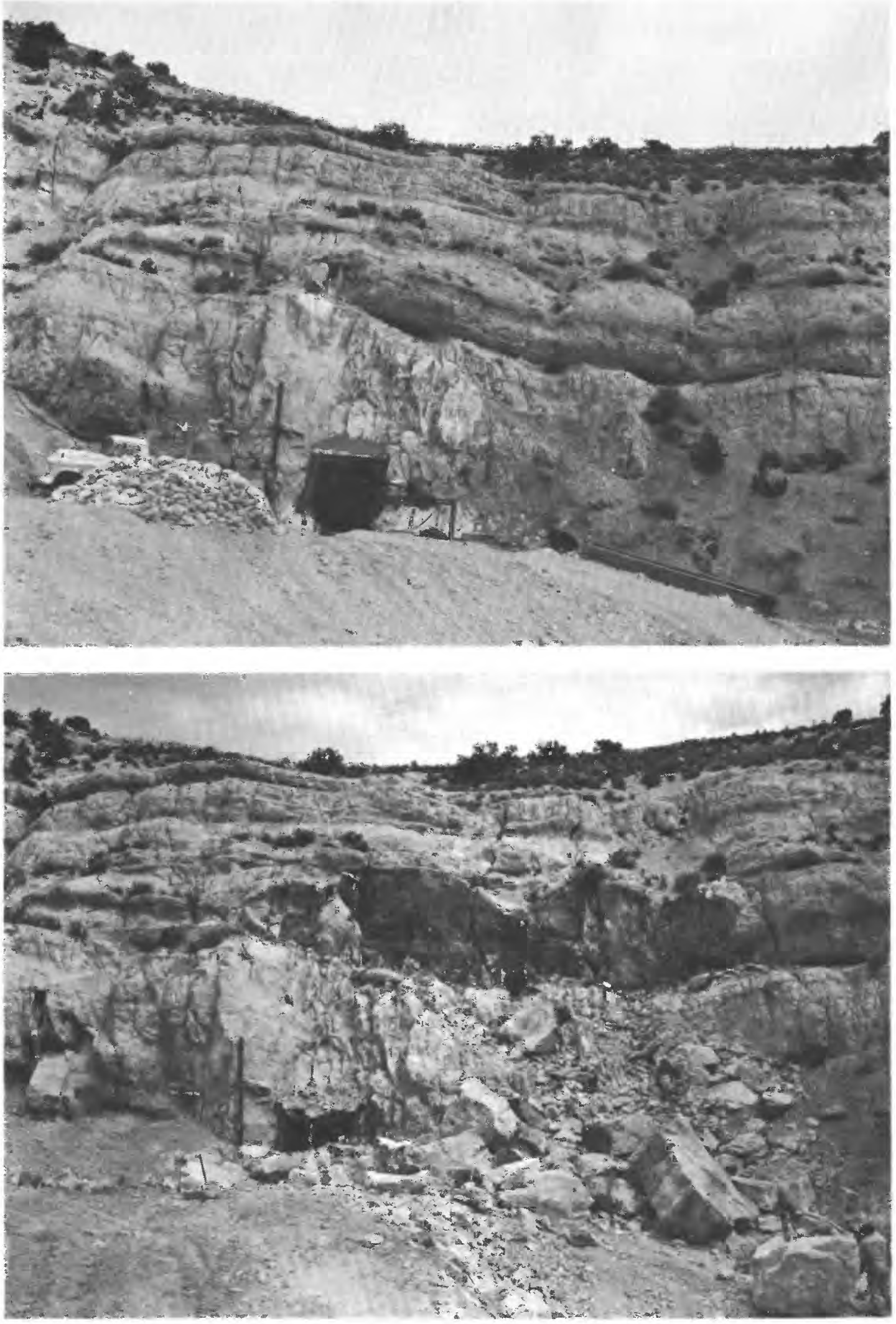

Figure 18. - Comparative views of portal area, USGS Tunnel, before (above) and after (below) 50-ton dynamite explosion in room B. Spalling of the cliff face above the portal was caused by rebound of the shock wave at the air-cliff interface, and damage to the portal cap timbers was caused by blocks of rock fallen from the cliff above. Inside the portal, the entry was undisturbed. Portal is about 340 feet from room B explosion chamber. 


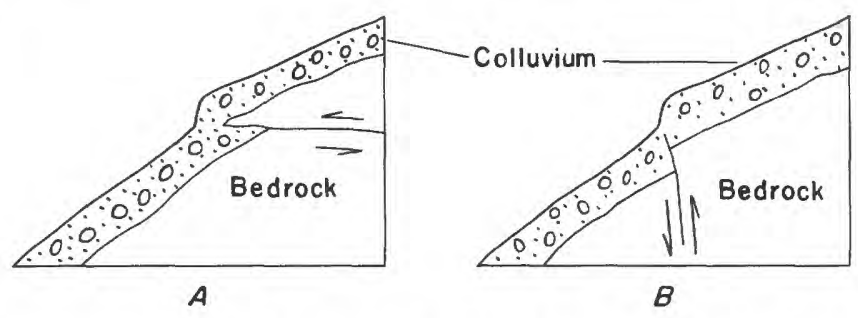

FiguRe 19.-Identical scarps in colluvium formed by low-angle displacement, $A$, and high-angle displacement, $B$. Unless the plane of displacement is exposed, the displacement of true movement can only be inferred.

greatest and where the need for data accordingly is greatest. In addition, most points were displaced radially by the blast.

In most directions from ground zero the point of no displacement is outside the map boundary. No attempt was made, however, to contour beyond the half foot of uplift line shown on the map (pl. 5) because of the wide spread between control points beyond that distance and because of marked local variations in the amount of displacement outside the line. Obviously, some points outside the half foot of uplift line were displaced more than half a foot because numerous scarps showing differential movement of more than half a foot were preserved outside the line. Some of these scarps, however, resulted from horizontal rather than vertical displacements on sloping hillsides; where the actual plane of displacement is obscured by a scree of mantle rock or colluvium, the resulting scarp appears the same in either case (fig. 19).

Inasmuch as the lines of equal uplift on the map (pl. 5) show only the vertical component of surface displacement, they do not represent fully the total dilatation of the hill caused by the blast. Nevertheless, they portray well the general configuration of the strongly updomed central area within a hundred feet or so of ground zero.

As was expected, the centers of strong uplift indicated by the precision surveys agree closely with the displacements shown on the ground by large scarps and fractures, and the lines of equal uplift outline faithfully the large individual blocks differentially uplifted by the blast just northwest and southeast of ground zero (pl. 5). It should be borne clearly in mind, however, that this updoming is residual and represents only the permanent uplift imposed on the hill by the explosion. The temporary updoming was much greater-in the central area above the explosion chamber it was almost four times as great.

\section{UNDERGROUND EFFECTS}

The dust cloud blown from the portal by the 10-ton explosion led to the premature assumption that the stemming had failed-as previously stated, remapping after the tunnel was cleaned out proved that the wall of the chamber had failed. To insure that the second explosion was completely confined, several methods of stemming were considered, including steel blast doors or a massive concrete plug to be designed to withstand the theoretical pressure expected. Such devices, however, would have greater strength than the enclosing rock to which they would be anchored. It seemed probable that the rock would fail and that the explosion would bypass any method of stemming that depended upon inherent, rigid strength. After a conference with E. W. Felegy, of the U.S. Bureau of Mines, the decision was reached that the most effective stemming method would be compartmentation of the tunnel with clay-bag barricades alternating with dead air chambers. Presumably, the nonrigid clay-bag barricades would be driven as a plastic plug into constrictions in the tunnel; the alternation of air chambers with barricades is a tried and effective method of absorbing explosive forces. A ready supply of clay was found in the playa deposits of Yucca Flat. Bags filled with this clay were moistened as they were laid in the barricades.

The 50 tons of dynamite did not completely fill room $\mathrm{B}$; so the surplus space in the room and about 3 feet of the lateral at the entrance of the room were stemmed to insure a high-order detonation (fig. 7). The east lateral to room $\mathrm{B}$ was stemmed from station $3+52$ to the corner at station $3+05$. The main tunnel was stemmed from stations $2+80$ to $2+60,2+38$ to $2+18$, and $0+52$ to $0+32$.

The first two clay-bag barricades in the tunnel, between stations $0+32$ and $0+52$ and between $2+18$ and $2+38$, were undisturbed by the blast except for falls of rock from the back. In the vicinity of station $2+00$ the tunnel was enlarged by spalling of the east wall, and fissures 2 to 6 inches wide and too deep to measure were opened in the back (pl. 4). Between the second and third barricades (fig. 7) the tunnel was completely blocked. For about the first 5 feet this blockage consisted of large broken rock fragments, but beyond station $2+43$ the muck and the rock in the walls was minutely fractured. This is the zone along the footwall of the major fault that crosses the tunnel. The rocks in this fault zone were highly brecciated before the explosion, and they were further broken by the force of the explosion. No postexplosion movement was discernible underground along the fault plane proper, although a displacement of nearly 2 feet was measured at one point at the surface.

The third barricade, in the footwall of the fault block between stations $2+60$ and $2+80$, was squeezed and twisted. This distortion resulted from closing up of 


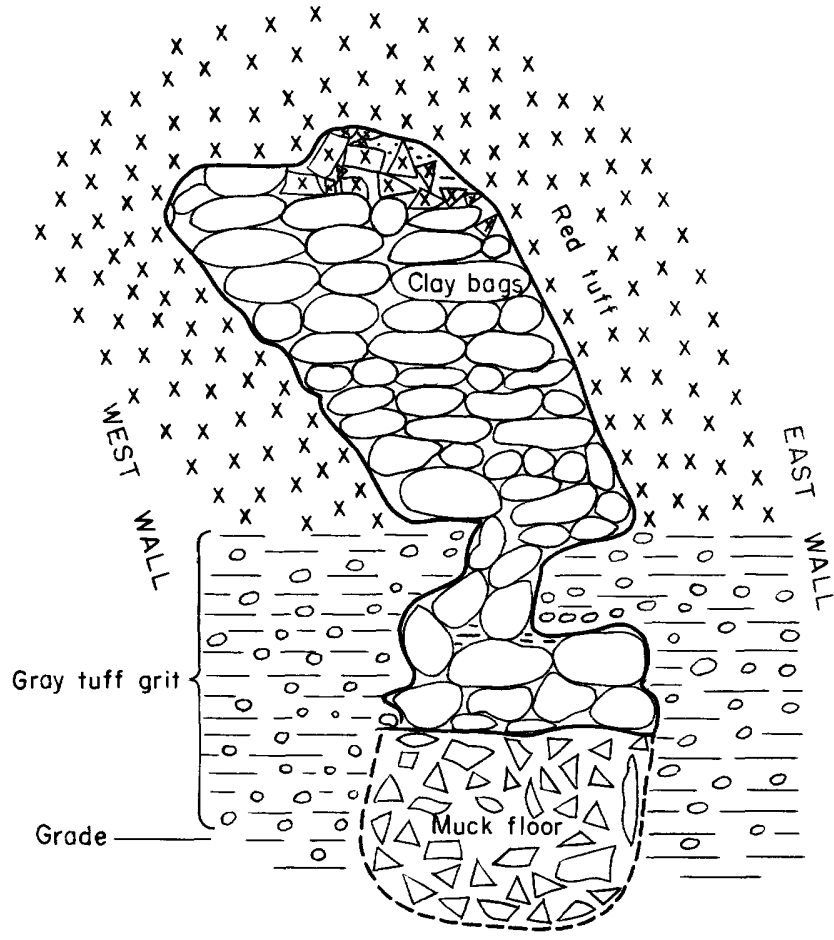

Figdre 20.- Canted outline of tunnel between stations $2+67$ and $2+84$.

the tunnel by movement of the walls, floor, and back. The upper part of the tunnel was pushed westward more than the lower part so that the outline of the tunnel, where preserved, was canted (fig. 20). Between stations $2+67$ and $2+84$ the upper part of the tunnel was in a moderately strong fine-grained bed of red tuff, but the lower part of the tunnel was in a gray tuff grit composed of $1 / 4^{-}$to $1 / 2$-inch fragments in a fine claylike matrix. This bed of grit was deformed like plastic, and, relative to the walls above, was squeezed inward from both sides (fig. 20). The back was minutely fractured, and the floor was raised as much as 1.5 feet above grade.

The barricade between stations $3+05$ and $3+52$ had been expected to be tightly compressed by direct force of the airblast, but when the corner at station $3+05$, was reexcavated, a strong natural ventilation of the tunnel was established. The direction of air circulation changes with atmospheric conditions-blowing inward from the portal toward the explosion chamber under some temperature and wind conditions, and outward from the barricade toward the portal under other temperature and wind conditions. The velocity of this air circulation and the reversal of directions of flow is indicative of very low resistance to the passage of air through the broken zone between the shot chamber and the surface.

During tunnel construction, a tugger station was excavated in the west wall of the main tunnel at station $3+05$. Before the blast this tugger station was alined with the centerline of the east lateral (pl. 4) ; after the blast it was 2 feet north of the alinement.

As a means of establishing relative movement of different parts of the tunnel, a series of steel rods 30 inches long had been set in pairs-one in the back directly over one in the floor. Table 2 shows preshot and postshot positions.

TABLE 2.-Preshot and postshot reference points

[Position after shots is given in feet with reference to centerline]

\begin{tabular}{|c|c|c|c|c|c|}
\hline \multirow{2}{*}{\multicolumn{2}{|c|}{ Preshots }} & \multicolumn{4}{|c|}{ Post shots } \\
\hline & & \multicolumn{2}{|c|}{ Floor } & \multicolumn{2}{|c|}{ Back } \\
\hline Station & Position & Station & Position & Station & Position \\
\hline $0+99.8 \ldots$ & 0.25 west of center- & & & & \\
\hline $2+01.8$ & On centerline & & & & \\
\hline $\begin{array}{l}2+32 \\
2+71.8 \\
-\ldots\end{array}$ & - & $\begin{array}{l}2+30.63 \\
2+70.8\end{array}$ & $\begin{array}{l}0.33 \text { west_. } \\
(?) \text {. }\end{array}$ & $2+29$ & $\begin{array}{l}0.65 \text { west. } \\
\text { Twisted, } 2.3\end{array}$ \\
\hline $\begin{array}{l}3+05 \\
4+30\end{array}$ & - & $\cdots$ & & $3+03.7$ & 2.4 west. \\
\hline
\end{tabular}

In addition, a point above the bedding plane between bed 21 and bed $22 \mathrm{a}$ at station $1+78$ moved 2.2 feet south and 0.5 foot west in relation to a point in the wall below that bedding plane. At the northwest corner of station $2+00$ the roof block above bed 21 moved 3.1 feet southwest; again, the block above bed 21 that was raised and. shifted by the 10-ton explosion was shifted farther by the 50-ton explosion.

A postshot resurvey of the centerline of the main tunnel shows that from stations $2+44$ to $2+82$ the east tunnel wall was pushed westward beyond the centerline, and that the north wall of the east lateral was pushed south beyond the centerline.

In preference to cleaning out the old east lateral, the main tunnel was extended northward to station $3+23$ north and a new lateral was driven eastward to the explosion chamber (pl. 4). The newly excavated ground was firm and very little disturbed. Fifty-eight feet east of the turn at station $3+23$ north the new lateral reached broken ground and at 62 feet east of station $3+23$ it broke into the explosion chamber (face I, pl. 4). This chamber is tightly filled with a rubble of broken rock. Two or three faces of many of the larger blocks are slickensided by the explosion. On one block a slickensided face cuts another slickensided face approximately at right angles, indicating that there had been two stages and directions of movement. A block of red tuff, from the portal bed, bed 20, measuring 6 by 6 by 14 feet, was dropped about 20 feet below its original stratigraphic position. Blocks of rock 
several feet across were driven into the wall or into other rocks. Dangerous conditions prevented any additional work in the explosion chamber.

At a point 40 feet east of station $3+23$ north in the new lateral a short drift was driven southward to the old lateral. The old lateral had moved 6.5 feet south of its originally surveyed position (pl. 4), and an open space, 1.5 feet wide, 5 feet high, and at least 7 feet deep, separated the north wall from the clay bags. The clay bags were blackened by powder smoke; and although they contained fly rock fragments, no signs of great compression were apparent.

Two raises were put up from the new east lateral; raise $I$ at station $0+40$ northeast, raise II at station $3+23$ north (pl. 4). In raise I a rubble of broken rock was found 12 feet above grade; in raise II similar material was found at about 30 feet. Indications were that this rubble was not merely on a plane along which the rock had been broken by shattering, but represented the base of a large mass of broken and displaced rock. The position and height of the raises indicate that the base of the broken rock dips about $30^{\circ}$ toward the explosion chamber and that the contact between broken and undisturbed rock should appear in the explosion chamber at the floor of the new east lateral at face $\mathbf{I}$; this, however, it does not do. It seems probable, therefore, that the zone of brecciation was controlled to some extent by bedding planes, a fracture following a bedding plane for a distance then breaking upward steplike across bedding to a higher plane.

The amount and direction of movement and fracturing underground cannot be measured or evaluated by simple calculations. The workings accessible to observation clearly show that large quantities of rock moved en masse away from the shot point. Within the mass, movements were differential from one point to another. Fairly well substantiated observations are summarized as follows:

1. The rock in the area close to the explosion chamber and along zones of weakness at greater distances was minutely fractured. These are zones in which the compressive forces of the explosion transmitted into the rock exceeded the compressive strength of the rock; the mineral grains are crushed and telescoped together.

2. The zones of minutely fractured material in the main tunnel are along preestablished planes of weakness, but they may also mark the boundary of a body that moved en masse.

3. Open fractures exist mainly outside the zone of compressive breakage, where the transmitted compressive forces were less than the compressive strength of the rock. In such situations the compressive forces of the explosion displace the rock outward; upon rebound the tensile strength of the rock is exceeded and open fractures result.

4. The lifting of a block, such as that above the bedding plane between beds 21 and $22 \mathrm{a}$, likely results from the lifting action of the shock wave.

The estimated volume (and tonnage) of rock broken and displaced by the 50-ton explosion is:

\begin{tabular}{|c|c|c|}
\hline Sphere of er & $\begin{array}{c}\text { Cubic yards } \\
4,200\end{array}$ & $\begin{array}{c}\text { Tons } \\
5,880\end{array}$ \\
\hline Cone of broken and displaced rock & 55,800 & 77,120 \\
\hline Cone of severely fractured rock & 490,000 & 680,000 \\
\hline
\end{tabular}

The overall volume damaged by the explosion, indicated by the outer limits of fracturing, is an irregularly shaped block of about 900,000 cubic yards $(1,250,000$ tons).

\section{CONTAINMENT OF THE 10-TON AND 50-TON EXPLOSIONS}

As classified by their surface and underground effects, the 10-ton and the 50-ton explosions at the U.S. Geological Survey site cannot be considered as contained explosions. The 10-ton shot is considered as intermediate between incipient and fractured, and the 50 -ton shot is considered as fractured. In both tests a value of $k=3.6$ in the formula $D=12.6 k \sqrt[3]{W_{1}}$ was used to determine the amount of dynamite to be used in relation to the depth of rock cover over rooms $\mathbf{A}$ and B. The resulting differences in the degree of breakage and fracturing between the 10-ton and the 50-ton tests substantiates the theory of the authors that for exact containment of an explosion the value of $k$ must increase with increased depth of rock cover.

The results of the 10-ton and the 50-ton shots were almost duplicated, at a smaller scale, in a number of the tests for containment of small explosions. In the comparable smaller tests, the $k$ factors were broken down by degree of surface breakage into $k_{f}$ ( $=k$ of test that fractured) and $k_{c}$ ( $k$ of test fully contained but with incipient fracturing). Comparing the $k_{f}$ and $k_{c}$ values of these small tests to the results of the 10-ton and 50-ton explosions the authors believe that the correct $\mathbf{k}_{c}$ value would have been 3.7 to determine the amount of dynamite in room $A$, and $k_{c}=4.1$ for the amount in room B. The computation follows:

The depth of rock cover over room $\mathbf{A}$ was 123 feet vertically, or 92 feet shortest (slope) distance to the surface. 
The depth of cover to the point of maximum breakage was about 98 feet: $98=12.6 \cdot 3.7 \sqrt[3]{W_{1}} \cdot W_{1}=9.3$ tons of 60 -percent nitroglycerine gelatin dynamite for exact containment in room $\mathrm{A}$.

The depth of rock cover over room B was 174 feet vertically, or 165 feet shortest distance to the surface.

The depth of cover to the point of maximum breakage was 174 feet: $174=12.6 \cdot 4.1 \sqrt[3]{W_{1}} \cdot W_{1}=38.2$ tons of 60-percent nitroglycerine gelatin dynamite for exact containment in room $\mathrm{B}$.

The original intention of the high-explosive tests was to use TNT as the explosive because the energy of nuclear blasts is generally rated as an equivalence of tons of TNT, and a direct comparison of the highexplosive tests to nuclear tests would be possible. The plan to use TNT was changed at a later date and the 60 -percent nitroglycerine gelatin dynamite substituted. This decision precludes the possibility of a direct comparison of these high-explosive tests with nuclear tests that are rated in terms of TNT. A preferable choice would have been 50-percent straight dynamite, for its energy is equal to that of TNT. An additional geologic factor to be considered in developing a scale of the effects of underground nuclear blasts is the wide variation of effects each type of explosive produces in different kinds of rock.

\section{LITERATURE CITED}

Du Pont de Nemours, E. I., \& Co., 1954, Blasters' handbook, $479 \mathrm{p}$.

Hansen, W. R., Lemke, R. W., Cattermole, J. M., and Gibbons, A. B., 1962, Stratigraphy and structure of the Rainier and USGS Tunnel areas, Nevada Test Site: U.S. Geol. Survey Prof. Paper 382-A (in press).

Johnson, G. W., and others, 1958, The underground nuclear detonation of September 19, 1957-Rainier operation Plumbbob : California Univ. Radiation Laboratory No. 5124.

Johnson, M. S., and Hibbard, D. E., 1957, Geology of the Atomic Energy Commission Nevada proving grounds area, Nevada : U.S. Geol. Survey Bull. 1021-K, p. 333-384.

Livingston, C. W., 1956, Fundamental concepts of rock failure, in Colorado School of Mines Quarterly: Rock Mechanics Symposium, v. 51, no. 3, p. 1-33.

Peele, Robert, 1918, Mining Engineers' Handbook : 1st ed., New York, John Wiley \& Sons, 237 p. 


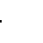




\section{INDEX}

Acknowledgments.

Page

Bedding plane, after 50-ton explosion before and after 10-ton explosion

$18,19,22,24,28$ $4,11,16$

Carbon monoxide, concentration

Cloud, dust.

13

Crater, sand, formation $11,12,15,18,26$

Deformation of area caused by 10-ton explosion.

Design of tunnel

Dip, of beds of Oak Spring formation of fractures..

Displacement, after 50-ton explosion maximum after 10-ton explosion in room $\mathrm{A}$............................... 15, 18

Du Pont de Nemours \& Co., eited.

Dynamite explosions in shallow drill holes

Edgerton, Germeshausen, \& Grier, Inc.

Effects of explosions in tests for containment

Effects of 50-ton explosion in room $B$.

Effects of 10-ton explosion in room $A$

Faults

Fieldwork

Fissures, in main tunne

in postshot chamber $A$

in postshot chamber $B$

Formulas for effects of explosives.

Fractures, opened by 50-ton explosion opened by 10 -ton explosion.

as, escape from tunnel.

Geology, surficial, mapping underground mapping 18

$5,7,8,9,10,28$

-. $18-28$

Joints

Juniper trees, effects of 10-ton explosion

Livingston, C. W., cited.

Location of USGS Tunne

Oak spring formation, explosions in geology
$5,6,11,15,16,18,21,22,26$

2-3

15

6,18

1,2

28

21

12,18

2-3

$2-3$
$2-5$

5,18

2 5
Peele, Robert, cited

Page

(11,

Purpose of high-explosive tests ............. 1-2

Purpose of report.

Rainier test.

Rainier Tunnel area.

Results of tests with 60 percent dynamite

Rock broken and displaced by 50-ton explosion, estimated volume (and ton-

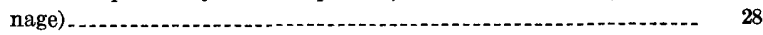

Rock damaged by 50-ton explosion, overall volume and tonnage

Room A, design

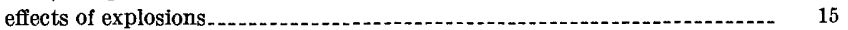

pattern of fractures opened by 10-ton explosion.

10-ton explosion. . .

Room B, design

faults before 50-ton explosion. 6

50-ton explosion. .

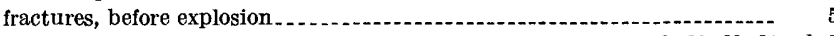

updoming after 50-ton explosion ...

Scarps, surface, result of 50-ton blast . . . . . . . .

Slickensides, on back of main tunnel after 10-ton explosion..................... 16, 19

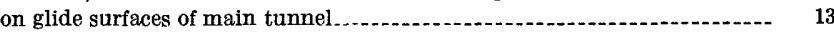

on rock in explosion chamber after 50-ton explosion

Stemming of tunnel. . . . .

Structure of tunnel area . .

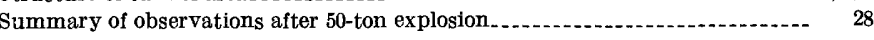

Temperature after 10-shot explosion in room A

Tensile strength of rock .

Tests for containment of small explosions results

TNT, in high-explosive tests. . . . yield in Rainier nuclear explosion

U.S. A tomic Energy Commission

Water content of Oak Spring formation

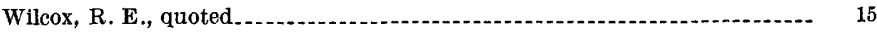

Yucca Flat.-1.-1

Zones of breakage of an explosion enclosed in a brittle material ............ 5, 7,8

B-31 
